2 sediments from tropical urban rivers, Kinshasa, Democratic Republic

\title{
of the Congo
}

4 Pitchouna K. Kilunga ${ }^{1}$, Periyasamy Sivalingam ${ }^{2}$, Amandine Laffite ${ }^{2}$, Dominique Grandjean ${ }^{3}$, Crispin K. Mulaji ${ }^{1}$, Luiz Felippe de Alencastro $^{3}$, Pius T. Mpiana ${ }^{1}$, John Poté $^{1,2 *}$

$6{ }^{1}$ University of Kinshasa (UNIKIN), Faculty of Science, Department of Chemistry, B.P. 190, Kinshasa XI,

7 Democratic Republic of the Congo

$8{ }^{2}$ University of Geneva, Faculty of Science, Department F.-A. Forel for Environmental and Aquatic Sciences, and

9 Institute of Environmental Sciences, 66, Boulevard Carl-Vogt, CH-1205, Geneva, Switzerland

$10{ }^{3}$ Ecole Polytechnique Fédérale de Lausanne (EPFL), Central Environmental Laboratory (GR-CEL), CH - 1015

11 Lausanne, Switzerland

12

13

14

\footnotetext{
* Corresponding author:

John Poté, PhD.

University of Geneva

Faculty of Sciences

Earth and Environmental Sciences

Department F.-A. Forel for environmental and aquatic sciences

Bd Carl-Vogt 66, CH-1211 Geneva 4

Switzerland

Tel: (+41 22) 3790321

Fax: (+41 22) 3790329

E-mail: john.pote@unige.ch
} 
The increasing contamination of fresh water resource by toxic metals and Persistence Organic Pollutants (POPs) is a major environmental concern globally. In the present investigation, surface sediments collected from three main rivers named, Makelele, Kalamu and Nsanga, draining through the city of Kinshasa, Democratic Republic of the Congo, were characterized for grain size, organic matter, toxic metals, POPs (including organochlorine pesticides (OCPs), polychlorinated biphenyls (PCBs), polybrominated diphenyl ethers (PBDEs)), and polycyclic aromatic hydrocarbons (PAHs). Furthermore, enrichment factor (EF) and geoaccumulation index (Igeo) were performed to determine metal source and pollution status. The results highlighted high concentration of toxic metals in all sediment samples, reaching the values $\left(\mathrm{mg} \mathrm{kg}^{-1}\right)$ of $325(\mathrm{Cu}), 549(\mathrm{Zn}), 165(\mathrm{~Pb})$ and $1.5(\mathrm{Cd})$. High values of PCBs and OCPs were detected in sediment samples, e.g. in Makele rivers, PCB values ranged from 0.910.9 with total PCBs ( $\sum 7$ PCBs x 4.3): $169.3 \mu \mathrm{g} \mathrm{kg}^{-1}$; OCPs from 21.6-146.8 with $\sum$ OCPs: $270.6 \mu \mathrm{g} \mathrm{kg}^{-1}$. The PBDEs concentrations were higher in investigated rivers comparatively with values detected in many rivers from Sub-Saharan Africa. The $\Sigma$ PAHs value ranged from 22.6 to $1011.9 \mu \mathrm{g} \mathrm{kg}^{-1}$. River contamination may be explained by local intense domestic activities, urban and agricultural runoff, industrial and hospital wastewaters discharge into the rivers without prior treatment. This research provides not only a first baseline information on the extent of contamination in this tropical ecosystem but also represents useful tools incorporated to evaluate sediment quality in the river receiving systems which can be applied to similar aquatic environments. 


\section{Introduction}

The water resource contamination by toxic metals and POPs is a worldwide problem because these chemicals are not degradable in the environment and can persist in sediments for decades or even centuries. Most of them are characterized by long-term stability and can have high toxic effects on aquatic living organisms (Wildi et al., 2004; Ghrefat and Yusuf, 2006; Thevenon et al., 2012; Mwanamoki et al., 2014b). Previous studies have highlighted that sediment as recipients and reservoirs of toxic heavy metals (Pote et al., 2008; Varol, 2011). In addition, accumulated toxic elements and POPs in sediments over the period of time serve as important indicators to assess and revaluate the pollution history (Mwanamoki et al., 2014a; Devarajan et al., 2015b; Doong et al., 2008). On the other hand, polluted sediments represent a significant source of contamination in freshwater organisms and have long- term implications for human health (Thevenon et al., 2013; Raghunath et al., 1999). The discharge of untreated urban effluents into river environments is a major concern in developing countries. Given this fact, in recent years accumulation of heavy metals in river sediments from developing countries have been reported with more attention (Mubedi et al., 2013; Devarajan et al., 2015b; Tamim et al., 2016; Laffite et al., 2016). Hydrophobic organic compounds (HOCs), such as PAHs, PCBs, and OCPs have been identified as environmental pollutants in all environmental compartments (Wu et al., 1999). Due to their high persistence and low solubility in water, HOCs can accumulate in sediments (Poté et al., 2008). European Union (EU) and the US Environmental Protection Agency (USEPA) highlighted that PAHs are of significant concern with regard to human health as having carcinogenic properties and bioavailability with water, soil, and sediments (Sindermann, 2006; Zhang et al., 2012). PCBs, PAHs, OCPs, and PBDEs are known to have extraordinary stability, high toxicity, extremely high long-range atmospheric transportability, and potential threats to human health and environmental ecosystems (Cui et al., 2016; Poto et al., 2012). Heavy metals, POPs and PHAs could be accumulated in aquatic organisms and eventually may transfer to higher order 
organisms including humans (Pardos et al., 2004; Huang et al., 2006; Díez et al., 2009). Therefore, it is important to assess the accumulation of toxic heavy metals and POPs in the environmental compartments to evaluate the ecological risk.

Kinshasa is the capital and largest city of the Democratic Republic of the Congo (DRC) and has an estimated population of more than 13 million. In Congo DR urban rivers are specially considered as several sources of pollution including sanitary landfills, mining activities, discharge of effluents from industries, hospitals, and urban activities. The Makelele, Kalamu, and Nsanga Rivers are the main rivers and tributaries of Congo River that drain the capital city of Kinshasa (Tshibanda et al., 2014; Mwanamoki et al., 2015). These rivers serve as sources of recreational use, bathing, drinking water supply and irrigation for urban agriculture. A very few comprehensive studies of heavy metals, pesticides and POPs in Congo River Basin have been conducted (Verhaert et al., 2013; Mwanamoki et al. 2014b; 2015; Laffite et al., 2016). These studies recommended further researches in the urban river receiving systems in studied area to evaluate the quality of the aquatic ecosystem. The levels of toxic metals, persistent organic pollutants (POPs: including organochlorine pesticides (OCPs), polychlorinated biphenyls (PCBs) and polybrominated biphenyl ethers (PBDEs), and polycyclic aromatic hydrocarbons (PAHs) in sediments are good indicators to evaluate the environmental quality of aquatic systems. Therefore, the objective of the present study was to discuss the occurrence and spatial distribution of toxic metals, POPs and PAHs in sediments from three of main rivers draining the capital city of Kinshasa. Sediment analyses were performed for the physicochemical characterization including sediment grain-size, total organic matter (loss on ignition), total carbon (TC), total phosphorus (TP), metals including $\mathrm{Cr}, \mathrm{Mn}, \mathrm{Fe}, \mathrm{Co}, \mathrm{Ni}, \mathrm{Cu}, \mathrm{Zn}, \mathrm{Mo}, \mathrm{Ag}, \mathrm{Cd}, \mathrm{Sn}, \mathrm{Sb}$, and $\mathrm{Pb}$, and persistent organic pollutants (including OCPs, PCBs, PBDEs) and PAHs. In addition, the degree of sediment pollution by 
heavy metals was evaluated using geo-accumulation index (Igeo) and enrichment factor (EF) calculation.

\section{Material and methods}

\section{1. $\quad$ Study sites and sampling procedure}

Three rivers named Makelele, Kalamu and Nsanga draining the capital city of Kinshasa (Fig. 1), DRC were selected in this study according to the recommendations of our previous studies (Mubedi et al., 2013; Tshibanda et al., 2014; Mwanamoki et al., 2014ab; 2015). Sampling took place in January 2016. The surface sediments (0-4 cm layer) were collected from (i) Makelele River (R1, n=3, labelled: R1A, R1B, R1C), (ii) Kalamu River (R2, n=4, labelled: R2A, R2B, R2C, R2D) and Nsanga River (R3, n=2, labelled: R3A, R3B). GPS location of sampling site is presented in Table-1.

Approximately 400-500 g of sediments were taken from each site in triplicate. The surface sediments from all sites were collected manually at about $0.3-1 \mathrm{~m}$ water depth. Sediment samples were kept in autoclaved glasses for POPs and PHAs analysis and in polyethylene bottles for other analyses. All samples were stored in an icebox at $4{ }^{\circ} \mathrm{C}$ that were transported to the laboratory for different treatments within $24 \mathrm{~h}$. After preliminary treatments, the samples were sent to the Department F.-A. Forel, the University of Geneva for analysis.

2.2. Sediment grain size and organic matter, total organic carbon, total nitrogen and phosphorus analysis

The particle grain size was measured in fresh sediment with a Laser Coulter® LS-100 diffractometer (Beckman Coulter, Fullerton, CA, USA), following 5 min ultrasonic dispersal in deionized water. The sediment total organic matter content was estimated from mass loss on ignition, at $550^{\circ} \mathrm{C}$ during 1 hour in a Salvis oven (Salvis AG, Luzern, Switzerland). 
The percentage of $\mathrm{TC}$ and Total Nitrogen (TN) was measured with an Elemental

113 Analyser (Perkin Elmer CHNS/O PE 2400 Series II, Waltham, MA, USA) by the following 114 conditions: Combustion Temperature: $975^{\circ} \mathrm{C}$, Reduction Temperature: $500^{\circ} \mathrm{C}$, Detection Oven: $82.2^{\circ} \mathrm{C}$, Pressure: $514.0 \mathrm{~mm} \mathrm{Hg}$. scientific, Waltham, USA) at $850 \mathrm{~nm}$. Fifty milligrams of dry sediments were diluted in $5 \mathrm{~mL}$

$1181 \mathrm{~N} \mathrm{HCl}$ in centrifuge tubes and ultrasonicated (at ambient temperature) for $16 \mathrm{~h}$ and then centrifuged at $4000 \mathrm{rpm}$ for $20 \mathrm{~min}$. The supernatant was mineralized for $45 \mathrm{~min}$ at $130^{\circ} \mathrm{C}$ after addition of $5 \% \mathrm{~K}_{2} \mathrm{~S}_{2} \mathrm{O}_{8}$ solution. The TP concentration was determined by measuring

121 the absorbance of the blue complex obtained after reduction of molybdophosphoric acid 122 according to the method described by Poté et al. (2008).

\subsection{Metal analysis in sediment samples}

125 Before analysis, the sediment samples were lyophilized, grounded into a fine homogenized, 126 and sieved through a $63 \mu \mathrm{m}$ mesh size sieve and digested according to the previous method as 127 described by Poté et al. (2008). The digested samples were subjected to analysis by Inductive 128 Coupled Plasma-Mass Spectroscopy (Agilent 7700x series ICP-MS developed for complex 129 matrix analysis, Santa Clara, CA, USA). A collision/reaction cell (Helium mode) and 130 interference equations were utilized to remove spectral interferences that might otherwise bias 131 results. This is sufficient for many routine applications. Multi-element standard solutions at 132 different concentrations $\left(0,0.02,1,5,20,100\right.$ and $\left.200 \mu \mathrm{g} \mathrm{L}^{-1}\right)$ were used for calibration. The 133 certified sediment reference materials LKSD-2 and LKSD4 were used for lake and river 134 sediment analysis in order to verify the sensibility of the instrument and the reliability of the 135 results, respectively. Concentrations are in $\mathrm{mg} \mathrm{kg}^{-1}$ (ppm) dry weight. The standard deviations 
136 of 3 replicate measurements were below $5 \%$, and chemical blanks for the procedure were less

137 than $1 \%$ of the sample signal.

\subsection{Geoaccumulation index and enrichment factor}

The enrichment factor (EF) and geo accumulation index (Igeo) in sediment samples

were calculated as described by Maanan et al. (2004), Varol (2011) and Thevenon et al.

141 (2012, 2013). The Igeo accumulation index is defined by the following equation:

142

Igeo $=\log _{2}\left(C_{n}\right) / 1.5\left(B_{n}\right)$

144

$145 \mathrm{Cn}$ : concentration of metals (n) examined in the sediment samples

146 Bn: concentration of the metal (n) geochemical background

147 1.5: lithospheric effect background correlation matrix factor

149 Enrichment factor is a useful tool to determine the degree of anthropogenic heavy metal

150 pollution. EF is calculated using the following equation, and according to our previous study,

151 Scandium (Sc) was used for the geochemical normalization (Mwanamoki 2014b).

$152 \mathrm{EF}=(\mathrm{metal} / \mathrm{Sc})$ sample $/($ metal/Sc) background

153

\subsection{Chlorinated pesticides, PCBs, PAHs and PBDEs analysis}

Chlorinated pesticides, PCBs, PAHs and PBDEs analysis was performed according to our previous paper as described by Mwanamoki et al. (2014b) and Thevenon et al. (2013).

157 Briefly: all glassware was rinsed with acetone and hexane and tested before using. Blanks do not present any quantifiable amount of contaminants or interfering compounds. After addition

159 of surrogate standards $\left({ }^{13} \mathrm{C}\right.$-labeled for all halogenated compounds and deuterated-labeled compounds for all PAHs), about $5 \mathrm{~g}$ of dry sediment were extracted with a mixture of $20 \%$ of 
acetone in $80 \%$ of hexane (v/v) for 4 hours into a Soxhlet system (Buchi B-811, Flawil,

162 Switzerland). Interfering sulfur compounds were removed by addition of activated copper to

163 the extract. Then, the organic extract was concentrated to $1 \mathrm{~mL}$ in a vacuum rotary evaporator

164 (Buchi Rotavapor, Flawil, Switzerland).

165 The extract was further submitted to fractionation and clean-up over a 166 chromatographic column containing $3 \mathrm{~g}$ of Silicagel, according to de Boer et al. (2001). Three

167 separated fractions were collected: first with $16 \mathrm{~mL}$ of hexane, than $35 \mathrm{~mL}$ of hexane, and 168 finally $50 \mathrm{~mL}$ of hexane: dichloromethane (v/v, 1:1). The first two fractions should contain 169 respectively PCBs and PBDEs. PAHs and chlorinated pesticides are distributed on the 3 170 fractions. After a new reduction of the volume, chemicals were measured by gas 171 chromatography with triple mass spectrometry detection (GC-MS/MS, Thermo Scientific, 172 TSQ Quantum XLS Ultra, Waltham, MA, USA). Two columns with different polarities, a 173 ZB-5ms column $(60 \mathrm{~m} \times 0.25 \mathrm{~mm} \times 0.25 \mu \mathrm{m})$ and one ZB-XLB column $(20 \mathrm{~m} \times 0.18 \mathrm{~mm} \times$ $1740.18 \mu \mathrm{m}$ ), were used for separation and identification of the different compounds. The choice 175 of the column for the identification of a specific compounds is mentioned on table $4 \mathrm{a}$ and $4 \mathrm{~b}$. 176 Chlorinated pesticides analyzed in sediment were: Hexachlorocyclohexane ( $\mathrm{HCH})$ (isomers 177 alpha, beta \& gamma) Heptachlor, Heptachlorepoxyde cis, Heptachlorepoxyde trans, 178 hexachlorobenzene, Aldrin, Dieldrin, Endrin, Oxy-chlordane, Alpha-chlordane, Gamma179 chlordane, Cis-nanochlor, Trans-nonachlor, o,p'-DDE (dichloro diphenyl dichlorethylene), 180 p,p'-DDE (dichloro diphenyl dichlorethylene), o,p'-DDD (dichloro diphenyl dichlorethane), 181 p,p'-DDD (dichloro diphenyl dichlorethane), o,p'-DDT (dichloro diphenyl trichlorethane), 182 p,p'-DDT (dichloro diphenyl trichlorethane) and Mirex. In the present work, results for DDT 183 compounds are given as EDDT, meaning the sum of the DDT and metabolites. These 184 pesticides are included in the Second Round of UNEP-coordinated Global Interlaboratory 185 Assessment 2012/2013 (UNEP-POPs, 2012). Selected congeners of PCBs searched were 
IUPAC numbers: CB-28 (2,4,4'-trichlorobiphenyl), CB-52 (2,5,2',5'- tetrachlorobiphenyl),

187 CB-101 (2,4,5,2',5'-pentachlorobiphenyl), CB-149 (2,3,6,2',4'5'-hexachlorobiphenyl), CB188118 (2,4,5,3',4'-pentachlorobiphenyl), CB-153 (2,4,5,2',4',5'-hexachlorobiphenyl), CB-105

189 (2,3,4,3',4'- pentachlorobiphenyl), CB-138 (2,3,4,2',4',5'- hexachlorobiphenyl), CB-128 190 (2,3,4,2',3',4'-hexachlorobiphenyl), CB-156 (2,3,4,5,3',4'- hexachlorobiphenyl), CB-180 191 (2,3,4,5,2',4'5'- heptachlorobiphenyl) and CB-170 (2,3,4,5,2',3',4'- heptachlorobiphenyl).

192 These CBs were used for certification purposes by the former Community Bureau of 193 Reference (BCR) of the European Union (Wells et al., 1992). Results are given as $\sum 12 \mathrm{PCBs}$ 194 meaning the sum of all CBs measured in a sample and also as "Total PCBs" meaning the sum 195 of 7 selected CBs $(28,52,101,118,138,153$ and 180) multiplied by a correction factor of 4.3 196 (FOEN, 1998).

PBDEs: Selected congeners were IUPAC numbers: BDE-17 (2,2',4-tribromodiphenyl ether), BDE-28 (2,4,4'-tribromodiphenyl ether), BDE-47 (2,2',4,4'-tetrabromodiphenyl ether), BDE66 (2,3',4,4'-tetrabromodiphenyl ether), BDE-85 (2,2',3,4,4'-pentabromodiphenyl ether), 200 BDE-99 (2,2',4,4',5-pentabromodiphenyl ether), BDE-100 (2,2',4,4',6-pentabromodiphenyl 201 ether), BDE-138 (2,2',3,4,4',5'-hexabromodiphenyl ether), BDE-153 (2,2',4,4',5,5'202 hexabromodiphenyl ether), BDE-154 (2,2',4,4',5,6'-hexabromodiphenyl ether), BDE-183 (2,2',3,4,4',5',6-heptabromodiphenyl ether), BDE-190 (2,3,3',4,4',5,6-heptabromodiphenyl ether). BDE-209 (decabrominated) was not analysed. $\sum$ PBDEs is the sum of all studied PBDEs. These PBDEs are included in the Second Round of UNEP-coordinated Global 206 Interlaboratory Assessment 2012/2013 (UNEP-POPs, 2012).

207 Quantitation limits (LOQ) defined as 10 times baseline noise, were comprised between 0.02 $208 \mathrm{ng} / \mathrm{g}(\mathrm{p}, \mathrm{p}$ '-DDE) and $0.15 \mathrm{ng} / \mathrm{g}$ for BDE-190 dry weight.

209 PAHs: Naphthalene, Acenaphthene, Fluorene, Phenanthrene, Anthracene, Fluoranthene, 210 Pyrene, Benzo(a)Anthracene, Chrysene, Benzo(e)Pyrene, Benzo(b)Fluoranthene, 
211 Benzo(k)Fluoranthene, Benzo(a)Pyrene, Dibenz(a,h)Anthracene, Benzo(g,h,i)Perylene, 212 Indeno $(1,2,3 \mathrm{c}, \mathrm{d})$ Pyrene, $\sum$ PAHs means the sum of all 16 studied PAHs. These PAHs are 213 similar to those proposed by US EPA to be measured in sediment samples, with exception of 214 Benzo(e)Pyrene and addition of Acenaphtylene.

215 The results for POPs and PAHs analysis are expressed in $\mu \mathrm{g} \mathrm{kg}^{-1}$ dry weight.

\subsection{Data analysis}

218 Triplicate measurements were performed for all the analyses. Statistical treatment of data 219 (Spearman's rank order correlation) has been realized using SigmaStat 12.5 (Systat Software, 220 Inc., USA). Principal Component Analysis (PCA), a multivariate statistical analysis was 221 performed using R (R Core Team, 2015) in order to understand relationship among analyzed 222 compound and their potential sources. Prior to performing PCA analysis, data were centered 223 in order to maximize the dispersion.

\section{Results and discussion}

\subsection{Physicochemical characteristics of sediments}

Sediment characteristics including particle grain size, OM, TC, TN, and TP are shown 228 in Table 1. The total OM in sediments ranged from 5.3 to 9.2, 7.2-12.6 and $1.7-13.4 \%$ for the sites R1, R2, and R3, respectively. There was no significant difference in total OM among all

230 samples (triplicate) from the same site. According to the results of our previous studies (Poté 231 et al., 2008; Haller et al., 2009; Mubedi et al., 2013), the organic matter in non-contaminated 232 freshwater sediments varied from $0.1-6.0 \%$. The results of this study indicated that the 233 sediment from studied sites can be considered as polluted/moderately polluted by organic 
matter. For example, OM can reach more than $30 \%$ in sediments contaminated by the municipal WWTP effluent waters (Poté et al. 2008; Devarajan et al., 2015a).

Surface sediments of rivers in all studied sites are generally sandy-silt. For all samples, the sand values ranged from $61.0-95.0 \%$ and silt from 5.8-39.0\%. The maximum value of clay was observed at the site R2A $(1.5 \%)$. The sediment median grain size varied substantially internally within the sampling sites $(\mathrm{p}<0.05)$. The values ranged from 46.8-105.3, 32.9-195.9 and 79.5-225.3 $\mu \mathrm{m}$ for $\mathrm{R} 1, \mathrm{R} 2$ and $\mathrm{R} 3$ respectively. In accordance with our previous report, the percentage of grain size in sediments observed in this study could probably be responsible for high porosity and high permeability, and further flexible transportation of the sediment downstream (Wildi et al., 2004; Thevenon et al., 2011; Bartoli et al., 2012). The values of TC content varied from 1.7-4.8, 2.1-7.2 and 1.7-2.4\% for R1, R2, and R3, respectively. The TN exhibited relatively low concentrations and a limited variability in sediments. The values ranged from 2.6-6.3, 2.8-3.6 and 1.8-4.2 $\mathrm{mg} \mathrm{kg}^{-1}$ for the sites $\mathrm{R} 1, \mathrm{R} 2$, and $\mathrm{R} 3$, respectively.

The total phosphorous contents of the sediments varied considerably with sampling sites $(\mathrm{p}<0.05)$. The values ranged from 92.6-242.7, 76.5-163.2, 67.4-89.8 $\mathrm{mg} \mathrm{kg}^{-1}$ for the sites $\mathrm{R} 1$,

R2, and R3, respectively. The results obtained are in agreement with our previous studies, which demonstrated that there are large variations in the distribution of TC, TN, TP and grain size in sediments from some urban rivers located in the city of Kinshasa (Mubedi et al., 2013; Tshibanda et al., 2014; Kilunga et al., 2016; Laffite et al., 2016).

\subsection{Metal concentrations in the surface sediments}

The results of the heavy metals analysis are presented in Table 2. It is noted that the concentrations of four heavy metals including $\mathrm{Cu}, \mathrm{Zn}, \mathrm{Cd}$ and $\mathrm{Pb}$ were found considerably higher in most of the sediment samples. The concentration of $\mathrm{Zn}$ was found to be higher than 258 the threshold level in all sediment samples and the value ranged from 128.1-549.6 $\mathrm{mg} \mathrm{kg}^{-1}$. 
259 The concentration of $\mathrm{Pb}$ was found to be in the range of $24.6-165.3 \mathrm{mg} \mathrm{kg}^{-1}$. It was observed 260 that the concentration of $\mathrm{Pb}$ generally high in all sediments except for the site $\mathrm{R} 2 \mathrm{~B}$. The 261 highest concentration of $\mathrm{Cu}$ was recorded at the site $\mathrm{R} 3 \mathrm{~B}$ with the value of $325.14 \mathrm{mg} \mathrm{kg}^{-1}$. 262 Similarly, for $\mathrm{Cd}$ at $1.5 \mathrm{mg} \mathrm{kg}^{-1}$ and $\mathrm{Pb}$ at $165.30 \mathrm{mg} \mathrm{kg}^{-1}$ in the same site. The concentration 263 of heavy metals including $\mathrm{Cu}, \mathrm{Zn}, \mathrm{Cd}$ and $\mathrm{Pb}$ recorded in this study were primarily compared 264 with the Sediment Quality Guidelines for the Protection of Aquatic Life (CCME EPC-98E 265 1999). The evaluation of the potentially deleterious effects of the metals towards benthic 266 fauna, which is based on consensus-based guidelines for the sediment quality (MacDonald et al., 2000a; Long et al., 2006), can give an estimate of the hazard that the sediments may represent for the local biota. Authors proposed (MacDonald et al., 2000a; Long et al., 2006)

269 for specific metals a "threshold effect concentration"' (TEC), a level above which some effect 270 (or response) will be produced in an organism and below which it will not, and a "probable 271 effect concentration" (PEC), a contaminant level that is likely to cause an adverse effect on 272 biota. Though distribution of heavy metals varied among all sampling sites, the concentration 273 of $\mathrm{Cu}, \mathrm{Zn}, \mathrm{Cd}$, and $\mathrm{Pb}$ is generally higher than the threshold level. Surprisingly, the 274 concentrations of $\mathrm{Zn}, \mathrm{Pb}$ and $\mathrm{Cd}$ are higher than that of the Congo River (Mwanamoki et al., 275 2014b; Mwanamoki et al., 2015). The results of the present stud show that the higher concentrations of $\mathrm{Cu}, \mathrm{Ni}, \mathrm{Zn}$, and $\mathrm{Pb}$ are likely to have a harmful effect on aquatic organisms.

277 Therefore, the sediments from Makelele, Kalamu and Nsanga Rivers can be considered as 278 highly polluted by heavy metals and this could be explained by various industrial sources and 279 urban discharge into the rivers. Urban rivers in Kinshasa seem to be under high threat and 280 stretch of the river running through urban areas is extremely polluted due to open drains, 281 sewage inflow and landfills. (Mavakala et al., 2016; Mwanamoki et al., 2015, Mubedi et al., 282 2013). However, the presence of other non-identified sources (such as artisanal activities) and 283 untreated hospital effluent water discharge cannot be excluded (Laffite et al., 2016). 


\subsection{Enrichment factor (EF) and Geoaccumulation index (Igeo)}

$\mathrm{EF}$ and Igeo values for selected metals in sediment samples from rivers are presented

in Table 3. The EF and Igeo indices are important in discriminating between anthropogenic metals and provide a quantitative criterion for characterizing the sediment according to the degree of metal pollution (Adamo et al., 2005). According to the Igeo values, pollution of toxic metals in studied sites was classified in the order of $\mathrm{Zn}>\mathrm{Pb}>$ and $\mathrm{Cu}$. The Igeo classification of "extremely polluted" was observed for $\mathrm{Zn}$ in samples from the sites R2C and R3B, and "heavily polluted" were observed in samples from R1A, R1B, and R2A. Other sites are "moderately to heavily polluted" level for $\mathrm{Zn}$. For $\mathrm{Pb}$, "moderately to heavily polluted" level was observed for all samples for the river R1, while the site $\mathrm{R} 2 \mathrm{C}$ and $\mathrm{R} 3 \mathrm{~B}$ present "heavily polluted" level. $\mathrm{Cu}$, Igeo values were ranged from -0.40 to 2.63 and the high Igeo value was observed in the site R3A. Based on the Igeo values of $\mathrm{Cu}$, except for the sites R2B and $\mathrm{R} 2 \mathrm{C}$, other sites were not polluted by $\mathrm{Cu}$.

The enrichment results were interpreted according to previous studies (e.g. Sakan et al., 2009; Mavakala et al., 2016). The EF values for $\mathrm{Cu}$ was ranged from 1.28 to 51.15, indicating "minor to extreme enrichment". For $\mathrm{Cu}$ the highest $\mathrm{EF}$ value was recorded at site R2A and R2B, indicating "extreme enrichment". Whereas, three sites (R2D, R3A, and R3B) for $\mathrm{Cu}$ showed lesser values of $\mathrm{EF}$ (1.28 to 1.58$)$, implied that there were minor enrichments of $\mathrm{Cu}$. The $\mathrm{EF}$ values for $\mathrm{Zn}$ ranged from 15.70 to 135.26 , indicating "severe to extremely severe enrichment". Intriguingly, Zn showed the highest EF values among the toxic metals investigated. The EF values of Zn for the sites R1A (88.43), R1B (79.69), R1C (92.49), R2A (84.80), R2B (68.38) and R2C (135.26) indicated "extreme enrichment". It was observed that the $\mathrm{EF}$ values of $\mathrm{Pb}$ ranged from 7.70 to 128.81 , which indicated that "moderately severe to extremely severe enrichment". Furthermore, the $\mathrm{EF}$ values of $\mathrm{Pb}$ revealed "extreme 
enrichment" for the sites R1C (78.35) and R3A (128.81) and very "severe enrichment" for the

310 sites R1A (42.78), R1B (38.88), R2A (43.64) and R2B (29.52). The results suggested that Zn

311 and $\mathrm{Pb}$ could be originated from anthropogenic sources. Whereas $\mathrm{Cu}$ might have originated

312 both from natural and anthropogenic sources (Mavakala et al., 2006; Mwanamoki et al., 313 2015).

\section{4. $\quad$ Spatial distribution of persistent organic pollutants in sediments}

The concentration of persistent organic pollutants (POPs) including organochlorine pesticides (OCPs), polychlorinated biphenyls (PCBs), polybrominated diphenyl ethers (PBDEs) and polycyclic aromatic hydrocarbons (PAHs) in surface sediments from river Makelele (R1), Kalamu (R2) and Nsanga (R3) are shown in Table 4a and 4b. All results are reported to dry weight. PCBs were detected in most surface sediment samples. In the current study 12 PCB congeners (PCBs 28, 52, 101, 105, 118, 128, 138, 149, 153, 156, 170 and 180) were detected. The sum of 12 PCBs ( $\sum 12$ PCBs) ranged between 3.46 to $52.94 \mu \mathrm{g} \mathrm{kg}^{-1}$. Comparison of the ( $\sum 7$ PCBs $x$ 4.3) PCBs for surface sediment samples at the nine sampling

324 sites in three different rivers revealed the maximum concentration for site R1C $\left(169.29 \mu \mathrm{g} \mathrm{kg}^{-}\right.$ $32{ }^{1}$ ), followed by R2D $\left(83.24 \mu \mathrm{g} \mathrm{kg}^{-1}\right)$ and R3B $\left(35.90 \mu \mathrm{g} \mathrm{kg}^{-1}\right)$. Concentrations increase from upper stream to downstream in all rivers, confirming the enrichment of PCBs coming from more heavily populated areas. In all sediments, the most abundant congeners were in order 153>138>180>149>101, penta and hepta chlorobiphenyls. These congeners are reflecting historic use of PCB mixtures containing penta, hexa and hepta chlorobiphenyls. This pattern

330 is somewhat different from Verhaert, et.al. (2013) who found a PCB pattern indicating 331 dominant use of Arochlor 1254. PCB 138, 153 and 180 are among the most persistent PCB 332 congeners, and have long half-life. As the use of commercial PCBs was forbidden in the 333 1980s, what we find here are a number of the most persistent PCB congeners, in this case in 
aquatic sediment environment. Fair enough, the pattern of PCB is reflecting historic use of

335 commercial mixtures but it is also important to stress that the pattern found in this study reflects high persistence (long half-life) (Stockholm Convention, 2017). MacDonald et al. (2000b) proposed values for TEL $\left(59.8 \mu \mathrm{g} \mathrm{kg}^{-1}\right)$ and PEC $\left(676 \mu \mathrm{g} \mathrm{kg}^{-1}\right)$ for "total PCBs", that we can compare with our $\sum 7$ PCBs x 4.3. Site R1C (Makelele River) and all sites (R2A, R2B, R2C and R2D) from Kalamu River presented higher concentrations than PEL value. To 340 understand the degree of contamination, the concentrations of PCBs in sediments from Rivers 341 Makelele, Kalamu and Nsanga were compared with PCB levels recorded in previous studies 342 in Congo DR and on other tropical developing countries.

The contents of ( $\sum 7$ PCBs x 4.3) PCBs were higher than those reported for the Congo

344 river basins (Verhaert et al., 2013; Mwanamoki et al., 2014b) and a similar site, Yamuna

345 River in Delhi in India (Kumar et al., 2013). However, concentrations of PCBs were lower as 346 compared to reported by Malik et al. (2014) from the sediment of Soan River, Pakistan (27.9-

$347116 \mu \mathrm{g} \mathrm{kg}^{-1}$ ). In order to investigate potential PCBs sources, PCA was performed (Fig. 2a).

348 The active variable was composed of the congeners composition of PCBs at different 349 sampling sites. The first component was mainly influenced (94.5\%) by the PCBs load. The 350 second component explains the relative congener composition in samples. Based on the 351 loading plot of the PCA, strong differences in PCBs load and relative congener pattern was 352 observed among the different R1, R2, and R3 sampling sites. Furthermore, all the PCBs were 353 correlated with each other $(\mathrm{R}>0.77, \mathrm{p}<0.05)$ but three cluster of highly strong correlation 354 between PCB congeners can be seen: 101-105-118 $(0.99<\mathrm{R}<1, \mathrm{p}<0.001), 138-149-153-156$ $355(0.99<\mathrm{R}<1, \mathrm{p}<0.001)$ and $170-180(\mathrm{R}=1, \mathrm{p}<0.001)$. These observations suggest that river 356 water quality in Kinshasa has been hugely impacted by a multi-diffuse direct discharge of 357 industrial (artisanal activities included) and urban waste water. Therefore, we suggest that the 358 urban and industrial untreated effluents and runoff water (one important source of PCBs being 
the atmospheric fallout), could be the on-going source of the contaminations of the presented

360 PCBs in sediments of three rivers.

For the 35 OCPs targeted in this study, only 14 were detected i.e. hexachlorobenzene,

$362 \beta$ - and $\gamma$-HCH, chlorpyrifos-ethyl, trans-nonachlor, p,p'-and o,p'-DDE, p,p'- and o,p'-DDD,

363 p,p'- and o,p'-DDT, cyhalothrin- $\lambda$, cypermethrin a, cypermethrin b and deltamethrin. None of

364 the OCPs $\alpha$ - and $\delta$-HCH, chlorpyrifos-methyl, $\alpha$-, $\gamma$ - and oxy-chlordane, dieldrin, endrin,

365 endrin aldehyde and ketone, heptachlor, heptachlor epoxid A and B, aldrin, endosulfan I and

366 II, endosulfan sulfate, methoxychlor, acetochlor and Mirex were detected. The non-detection

367 of these OCPs may be due to their regulation and/or banishment by US EPA and European

368 directives. Figure $2 \mathrm{~b}$ shows the results of PCA analysis for OCPs. The first and second

369 components explained $59.7 \%$ and $27.5 \%$ of the total variance. The first component was

370 mainly influenced by the quantity of OCPs while the second component was influenced by

371 congeners composition. All sites are grouped in the same cluster in reason of a similar OCPs

372 mixture, but R1A and R1C differ from the other sites because of their strong contamination

373 by DDT and its derivatives at R1A site and chlorpyrifos-ethyl \& deltamethrin at the R1C site.

374 Pyrethroids pesticides like cypermethrin, cyhalothrin and deltamethrin have all

375 neurotoxic effects and may cause adverse health effects in humans. Cypermethrin and

376 deltamethrin are highly toxic to aquatic life, especially fish. The concentration of deltamethrin

377 ranged from 27.3 to $227.5,32.2-97.3$ and $12.5-69.1 \mu \mathrm{g} \mathrm{kg}^{-1}$ for the River Makelele, Kalamu

378 and Nsanga respectively. Since the year 2013, the Ministry of Agriculture of DRC has

379 approved the import, sale, and use of deltamethrin and chlorpyrifos for insecticidal

380 applications in agriculture (M.A.P., 2016). As a result, the above - mentioned chlorinated

381 pesticides has been intensively used regularly in urban agriculture. Furthermore, many

382 hospitals nearby urban river sites have been using insecticides for cleaning purposes. On other

383 hand, the agricultural runoff and untreated hospital effluent waters are discharged into the 
384

385

river receiving systems without regulation. These aspects might have attributed to the high concentration of deltamethrin and other chlorinated pesticides at the studied sites, mainly in the site R1C (Makelele River) located near a great hospital discharging the effluent waters without previous treatment.

OCPs including p,p'-DDE, o,p'-DDE, p,p'-DDD, o,p'-DDD, p,p'-DDT and o,p'-DDT were detected in all sediments as shown in Table 4. In all sediments, the most dominant isomers were in order p,p'-DDE > p,p'-DDD> p,p'-DDT > o,p'-DDT> o,p'-DDD and o,p'DDE. The highest concentrations of $\sum 6$ DDTs were recorded in the sediments from the Makelele River for site R1A $\left(270.61 \mu \mathrm{g} \mathrm{kg}^{-1}\right)$, whereas the lowest values detected at the site R3A (1.23 $\left.\mu \mathrm{g} \mathrm{kg}^{-1}\right)$, Nsanga River. The fluctuations observed in the total concentrations of $\sum 6$ DDTs suggest different emission sources on river basins or a dilution by clean sediments. The total concentrations of DDTs in all sediments was found to be higher than the TEL and PEL values except for the site R3A. A previous study reported that DDT could be converted into DDE by biodegradation under aerobic conditions via dehydrochlorination and oxidation process, and into DDD involving reductive dechlorination under anaerobic conditions (Syed et al., 2014). Similarly, our results showed elevated concentrations of DDE and DDD. The total concentrations of $\sum 6$ DDTs detected in surface sediments in this study present an extreme increase in comparison to those previously detected in Congo River (Verhaert et al., 2013; Mwanamoki et al., 2014b). According to Li et al. (2016), it is possible to establish if DDTs input is historic or recent origin using the ratio between the concentrations of (DDD + $\mathrm{DDE}$ )/DDT. If the ratio is greater than 0.5 in the first case, indicates historic and less than 0.5 indicates recent input. The values of (DDD + DDE)/DDT ranged from 2.7 to 6.12, 2.2-8.9 and 2.2- 4.1 for the River Makelele, Kalamu, and Nsanga, respectively. These results suggest that the rivers have been exposed to DDT from historic use, but may also be derived from indoor household appliances and agricultural misuse. DDTs are one of the important OCPs in 
connection with human and aquatic organism's health. According to WHO report, DDTs have

410 been permitted for indoor household appliances in Congo DR for fighting against malaria 411 vector (WHO, 2011). This could also possibly responsible for the elevated level of DDTs 412 along the river basins.

$413 \sum$ 6-PBDEs concentration ranged from 1.5-27.9 $\mu \mathrm{g} \mathrm{kg}^{-1}$. BDE-47 and BDE-99 were the most 414 abundant in all sites. We observe a concentration enrichment from upper stream to 415 downstream in R1and R2 rivers. Figure 2c represent the results of PCA analysis for PBDEs. 416 The PCA first component explained $98.3 \%$ of the total variance and was mainly influenced by 417 contamination level. Only $1 \%$ of the total variance was explained by the second component. 418 The different sites showed substantial differences between each other, highlighting the 419 variability of PBDEs load and congener mixture in the sediment. Canadian Federal 420 Environmental Quality Guidelines (FEQGs, 2013) recommended the threshold level of 44, $42139,0.4,440,5600$ and $19 \mu \mathrm{g} \mathrm{kg}^{-1} \mathrm{dw}$ in sediment for tri, tetra, penta, hexa, octa, and deca BDEs respectively. The BDE99 concentrations at all sites exceed the recommended value of $0.4 \mu \mathrm{g} \mathrm{kg}^{-1} \mathrm{dw}$. The BDE100 concentrations were found higher than the threshold level of 0.4 $424 \mu \mathrm{g} \mathrm{kg}^{-1} \mathrm{dw}$ for most of the sediment samples. Coal combustion, urban sewage, the oil spill 425 from the pirate garages and electronic wastes along the river basins were probably the 426 possible sources of PBDEs in sediments. It should also be noted that the concentrations are 427 much higher than in a previous work on Congo River Basin, DR Congo, where Verhaert et al. 428 (2013) measured between below limits of quantification and $1.9 \mu \mathrm{g} \mathrm{kg}^{-1} \mathrm{dw}$ for the sum of 8 429 BDEs, the same than in our case, more BDE-183 and BDE-209. BDE-209 represents near 90 $430 \%$ of $\sum 8$-BDEs, followed by BDE-47 and BDE-99, $5 \%$ and $3 \%$ respectively. In another 431 study on sediments from 6 rivers from Gauteng, South Africa, Olukunle et al. (2015) 432 measured similar concentrations than in our study, values ranged from $0.82 \mu \mathrm{g} \mathrm{kg}^{-1}$ and $44 \mu \mathrm{g}$ $433 \mathrm{~kg}^{-1}$ for the sum of 8 PBDEs congeners, including BDE-209. Here, BDE-100, BDE-99 and 
434 BDE-47 were the most abundant congeners. In their study on 4 sampling sites from 435 Murchison Bay of Lake Victoria, Uganda et al. (2012) measured concentrations ranged from 0.060 and $0.179 \mu \mathrm{g} \mathrm{kg}^{-1}$ for the sum of 11 PBDE congeners.

The concentrations of individual PAHs investigated in the current study are presented in Table 4a. All investigated PAHs were detected in most sediments. The concentrations of $\Sigma 16$ PAHs in surface sediments ranged from 22.56-1011.94 $\mathrm{g} \mathrm{kg}^{-1}$. Based on PCA loading 440 plot (Fig. 2d), we observed a strong correlation among all the congeners $(\mathrm{R}>0.83, \mathrm{p}<0.01)$ except for naphthalene $(0.40<\mathrm{R}<0.74)$. The first component, which explains $93.3 \%$ of the total variance, was mainly influenced by the PAHs concentration in the sediment and the second component (4.9\% of the total variance) was influenced by the PAHs mixture 444 composition. PCA results showed that the composition of PAHs mixture differs substantially 445 from site to site. The highest concentration for $\Sigma 16$ PAHs was observed at R1C, while the lowest was recorded at R3A. Again, concentrations are higher downstream in R1 and R2 447 rivers, confirming the enrichment of PAHs across the more populated areas. As for $\sum \mathrm{PCBs}$, 448 EDDT, sampling point R1C on Makelele River is the most contaminated one. The results 449 indicate that moderate to heavy contamination of sediments by PAHs. According to 450 MacDonald et al. (2000b), proposed values for TEL were (1 $\left.610 \mu \mathrm{g} \mathrm{kg}^{-1}\right)$ and PEL (22 $800 \mu \mathrm{g}$ $451 \mathrm{~kg}^{-1}$ ) for the sum of 13 PAHs (the 16 PAHs analyzed in this work with exception of: Dibenzo 452 (a,h) Anthracene, Benzo (g,h,i) Perylene and Indeno (1,2,3c,d) Pyrene). In general, the 453 detection level of the sum of Phenanthrene concentrations in all 9 sediments $\left(635.24 \mu \mathrm{g} \mathrm{kg}^{-1}\right)$ 454 and of Pyrene (550.36 $\mu \mathrm{g} \mathrm{kg}^{-1}$ ) were found to be the most dominant PAHs among all 455 sediments, followed by those of Naphthalene $\left(457.86 \mu \mathrm{g} \mathrm{kg}^{-1}\right)$ and those of Fluoranthene $456\left(410.79 \mu \mathrm{g} \mathrm{kg}^{-1}\right)$. The detection level of the sum of Acenaphthylene in all sediments was the 457 lowest $\left(34.24 \mu \mathrm{g} \mathrm{kg}^{-1}\right)$ among the 16 PAHs investigated in this study. As shown in Table 4, 458 the high molecular weight (HMW, 4-6 aromatic rings) PAHs were predominant in surface 
sediments. The total concentrations of ( $\sum 13$ PAHs) in all sediments was found to be lower than the TEL value except for the sites R1C and R2B. However, the total concentrations of 13 PAHs in all sediments was found be lower than the PEL $\left(22800 \mu \mathrm{g} \mathrm{kg}^{-1}, \mathrm{dw}\right)$. Yang et al. (2013) reported that soils and sediments are the primary steady sinks for PAHs in the environmental compartments. A similar trend was observed in surface sediments of the current study. Furthermore, the results were in similar to that previously reported for rivers (Kanzari et al., 2014). However, it was noted that the concentrations of PAHs were higher than our previous study (Mwanamoki et al., 2014b) from the sediment of Congo River basins (34.48 to $\left.63.89 \mu \mathrm{g} \mathrm{kg}^{-1}\right)$.

Yunker et al. (2002) reported that PAHs can originate from natural or anthropogenic processes. To better understand the potential source of PAHs, four diagnostic ratios were calculated in this study. According to Yunker et al. (2002) and Manneh et al. (1997), it is possible to establish if PAHs are from petrogenic or pyrogenic origin using the ratio between the concentrations of Fluo/(Fluo + Pyr) or IDP/(IDP + BghiP). If the ratio is $<0.4$ in the first case, the source is petrogenic, when it is between 0.4 and 0.5 the source is petroleum combustion, and when it is $>0.5$, the source is grass, wood, or coal combustion. The ratio of $\mathrm{IDP} /(\mathrm{IDP}+\mathrm{BghiP})$ smaller than 0.2 indicates the source is petrogenic; a ratio ranged from 0.2 to 0.5 is considered as the source of petroleum combustion, a ratio greater than 5 indicates grass, wood, or coal combustion (Manneh et al., 2016). Furthermore, the ratio of $\mathrm{BaA} /(\mathrm{BaA}+\mathrm{Chry})$ smaller than 0.2 is generally considered as petroleum source, a ratio between 0.2 and 0.35 indicates either a petroleum or combustion source and a ratio greater than 0.35 indicates pyrolytic origin (Manneh et al., 2016). In addition, Budzinski et al., (1997) propose that if the LMW/HMW ratio is smaller than 1, the source is petrogenic, when it is higher than 1, the source is pyrogenic. According to ratio as explained above, the results for sediment samples from Makelele and Nsanga Rivers suggested that the PAHs probably have 
484

485

originated from petrogenic processes and/or petroleum combustion (Table 5). The PAHs pollution in Kalamu River were probably originated from petrogenic and pyrogenic sources (combustion of fossil fuel). However, it should be noticed that the studied rivers take their sources upstream, in the savannas region, before arriving in the city. People leaving in the savannas burn the forest and the herbs for their crops without any regulation. Also in the city of Kinshasa, over $70 \%$ of the inhabitants use coal and wood to cook. This combustion of coal and wood could explain the origin of some PAHs along these rivers.

For more than 45 years, PAHs, PCBs, OCPs, and PBDEs have been of great environmental concern. Consequently, several studies have been performed to assess their levels and potential risk in air, soil, and surface sediments of rivers and lakes from Europe and the United States (e.g. Degrendele., 2016; Kanzari et al., 2014; Thevenon et al., 2013; Desmet et al., 2012; Echols et al., 2012; Poté et al., 2008). In many cases, the levels of PCBs in sediments are higher than those detected in this study. However, the PAHs concentration presented in this study were higher than those observed in our previous study in sediments from Swiss Lakes (Pardos et al., 2004; Poté et al., 2008; Thevenon et al., 2013).

\subsection{Correlation between parameters}

The Spearman's rank-order correlation values are presented in Table 6. The results showed a significant positive correlation among the metals $\mathrm{Zn}, \mathrm{Pb}$, and $\mathrm{Cd}$. $\mathrm{Zn}$ showed strong positive correlation with $\mathrm{Cd}(\mathrm{r}=0.917, \mathrm{p}<0.05, \mathrm{n}=9)$ and $\mathrm{Pb}(\mathrm{r}=0.9, \mathrm{p}<0.05, \mathrm{n}=9) . \mathrm{Cd}$ also displayed positive correlation with $\mathrm{Pb}(\mathrm{r}=0.733, \mathrm{p}<0.05, \mathrm{n}=9)$. These results indicated that these metals could have originated from common sources with a similar transport pathway (runoff and streams) (Poté et al., 2008; Haller et al., 2009). The negative correlation between total organic carbon and $\mathrm{Cd}$ indicating a possible multiple sources and transport pathway, which may be the discharge of domestic wastes from the urban population. On the 
whole, the results suggested that these toxic metals could have originated from multiple

510 sources into the river receiving systems. Total organic matter displayed positive correlation 511 with PAHs $(\mathrm{r}=0.733, \mathrm{p}<0.05, \mathrm{n}=9)$ and PBDEs $(\mathrm{r}=0.767, \mathrm{p}<0.05, \mathrm{n}=9)$ indicating that 512 probably had a similar source such as from point source of dumping of urban waste and 513 industrial activities on the river basins and combustion of coal, wood and fossil fuel. The 514 negative correlative between grain size and PBDEs indicating that the diverse pollution 515 source, possibly from electronic waste. PCBs showed strong positive correlation with TC, 516 indicating PCBs were more likely come from urban surface runoff. In addition, DDTs showed 517 strong positive correlation with $\mathrm{TP}$, indicating that the DDTs accumulation in the sediments 518 could be attributed to urban activities, pesticide abuse, and household runoff. Furthermore, a 519 positive correlation was observed between PCBs and PAHs. This result suggested that PCBs 520 and PAHs might have had common sources and transport pathway like an urban runoff. 521 Consequently, it becomes clear that industrial wastewater, urban effluents, artisanal activities, 522 dumping the huge amount of urban waste and combustion of coal, wood, and fossil fuel were 523 the main contribution sources of toxic metals and micro pollutants in the studied areas.

\section{$524 \quad 4 . \quad$ Conclusion}

525 This study provides an extensive data on heavy metals, POPs and PAHs contamination level 526 in Makelele, Kalamu and Nsanga Rivers in Congo DR. The results indicated that four toxic 527 heavy metals including $\mathrm{Cu}, \mathrm{Zn}, \mathrm{Cd}$ and $\mathrm{Pb}$ were predominantly detected in most of the 528 sediments and the contamination level was higher than other Congo River basins. Makelele 529 River is the most contaminated in comparison with two others investigated rivers in the 530 present study. In addition, the concentration levels of PCBs, DDTs and PAHs were generally 531 high in Makelele River and it warrants the important steps on limit the input sources to 532 prevent further food web contamination. The PBDEs concentrations were higher in 533 investigated rivers comparatively with some values detected in many rivers from Sub-Saharan 
534 Africa. It was also noted that PAHs represented the highest contributor of organic micro-

535 pollutants pollution in these rivers. Our findings suggest that these rivers were heavily 536 polluted and may pose a great risk to human health and aquatic environment. Further research

537 in aquatic organisms such as fish from these rivers may provide more comprehensive 538 information on contaminants with regard to the aquatic life and human health. Industrial 539 effluents, untreated urban effluents, automobile exhaust, e-waste, improper incineration of 540 urban waste in landfills, run off, petroleum combustion and pyrogenic activities could be the 541 major contributors for the investigated contaminants for the studied sites. Our study will be 542 useful for the establishment of effective water management strategies in urban river 543 ecosystems in Congo DR, which can be applied in similar aquatic environment.

\section{Acknowledgements}

546 We are grateful to financial support from the Swiss National Science Foundation (grant no. 547 31003A_150163/1). Authors thank Profs. Marie Besse and Patrycja Paruch, and Mme Brigitte 548 Mantilleri, Service égalité - UNIGE for financial support to Pitchouna Kilunga during her 549 training at University of Geneva. Periyasamy Sivalingam is a Postdoctoral fellow supported 550 by Swiss Government Excellence Scholarship for Foreign Scholars. This study presents a 551 collaboration between University of Geneva (Forel Department) and University of Kinshasa 552 (Democratic Republic of the Congo).

554 References

555 Bartoli, G., Papa, S., Sagnella, E., Fioretto, A., 2012. Heavy metal content in sediments along the Calore river: Relationships with physical-chemical characteristics. Journal of Environmental Management 95, Supplement, S9-S14. 
Budzinski, H., Jones, I., Bellocq, J., Piérard, C., Garrigues, P., 1997. Evaluation of sediment contamination by polycyclic aromatic hydrocarbons in the Gironde estuary. Marine Chemistry 58, 85-97.

Cui, S., Fu, Q., Guo, L., Li, Y.-F., Li, T.-x., Ma, W.-1., Wang, M., Li, W.-1., 2016. Spatialtemporal variation, possible source and ecological risk of PCBs in sediments from Songhua River, China: Effects of PCB elimination policy and reverse management framework. Marine Pollution Bulletin 106, 109-118.

CCME EPC-98E (Canadian Council of Ministers of the Environment),1999.Canadian Sediment Quality for the Protection of Aquatic Life.<http://www.ccme.ca/>

CCME (Canadian Council of Ministers of the Environment), 2002. Canadian sediment quality guidelines for the protection of aquatic life. Canadian Environmental Quality Guidelines.

FEQGs, 2013. Canadian Environmental Protection Act, 1999. (2013). Federal Environmental quality guidelines Polybrominated Diphenyl Ethers (PBDEs). $<$ Https://www.ec.gc.ca/ese-ees/>

de Boer, J., Allchin, C., Law, R., Zegers, B., Boon, J.P., 2001. Method for the analysis of polybrominated diphenylethers in sediments and biota. TrAC Trends in Analytical Chemistry 20, 591-599.

Degrendele, C., Audy, O., Hofman, J., et al., 2016. Diurnal variations of air-soil exchange of semivolatile organic compounds (PAHs, PCBs, OCPs, and PBDEs) in a Central European Receptor Area. Environ. Sci. Technol. 50, 4278-4288.

Desmet, M., Mourier, B., Mahler, B.J., et al., 2012. Spatial and temporal trends in PCBs in sediment along the lower Rhône River, France. Sc. Total Environ. 433, 189197.

Devarajan, N., Laffite, A., Graham, N.D., Meijer, M., Prabakar, K., Mubedi, J.I., Elongo, V., Mpiana, P.T., Ibelings, B.W., Wildi, W., and Poté, J. (2015a). Accumulation of 
Clinically Relevant Antibiotic-Resistance Genes, Bacterial Load, and Metals in Freshwater Lake Sediments in Central Europe. Environmental Science \& Technology 49, 6528-6537. doi: 10.1021/acs.est.5b01031.

Devarajan, N., Laffite, A., Ngelikoto, P., Elongo, V., Prabakar, K., Mubedi, J.I., Piana, P.T.M., Wildi, W., Poté, J., 2015b. Hospital and urban effluent waters as a source of accumulation of toxic metals in the sediment receiving system of the Cauvery River, Tiruchirappalli, Tamil Nadu, India. Environmental Science and Pollution Research

Díez, S., Delgado, S., Aguilera, I., Astray, J., Pérez-Gómez, B., Torrent, M., Sunyer, J., Bayona, J.M., 2009. Prenatal and Early Childhood Exposure to Mercury and Methylmercury in Spain, a High-Fish-Consumer Country. Archives of Environmental Contamination and Toxicology 56, 615-622.

Doong, R.-a., Lee, S.-h., Lee, C.-c., Sun, Y.-c., Wu, S.-c., 2008. Characterization and 596 composition of heavy metals and persistent organic pollutants in water and estuarine sediments from Gao-ping River, Taiwan. Marine Pollution Bulletin 57, 846-857.

Echols, K.R., Brumbaugh, W.G., Orazio, C.E., May, T.W., Poulton, B.C., Peterman, P.H., 599

600

601 2008. Distribution of Pesticides, PAHs, PCBs, and Bioavailable Metals in Depositional Sediments of the Lower Missouri River, USA. Archives of Environmental Contamination and Toxicology 55, 161-172.

FOEN - Swiss Federal Office for the Environment, 1998. Ordonnance du 1er juillet 1998 sur les atteintes portées aux sols (OSol). RS 814.12, Berne.

Ghrefat, H., Yusuf, N., 2006. Assessing Mn, Fe, Cu, Zn, and Cd pollution in bottom sediments of Wadi Al-Arab Dam, Jordan. Chemosphere 65, 2114-2121. 
Haller, L., Poté, J., Loizeau, J.-L., Wildi, W., 2009. Distribution and survival of faecal indicator bacteria in the sediments of the Bay of Vidy, Lake Geneva, Switzerland. Ecological Indicators 9, 540-547.

Hsu, L.-C., Huang, C.-Y., Chuang, Y.-H., Chen, H.-W., Chan, Y.-T., Teah, H.Y., Chen, T.Y., Chang, C.-F., Liu, Y.-T., Tzou, Y.-M., 2016. Accumulation of heavy metals and trace elements in fluvial sediments received effluents from traditional and semiconductor industries. Scientific Reports 6, 34250.

Huang, X., Hites, R.A., Foran, J.A., Hamilton, C., Knuth, B.A., Schwager, S.J., Carpenter, D.O., 2006. Consumption advisories for salmon based on risk of cancer and noncancer health effects. Environmental Research 101, 263-274.

Jain, C.K., Singhal, D.C., Sharma, M.K., 2005. Metal Pollution Assessment of Sediment and Water in the River Hindon, India. Environmental Monitoring and Assessment 105, 193-207.

Kanzari, F., Syakti, A.D., Asia, L., Malleret, L., Piram, A., Mille, G., Doumenq, P., 2014. Distributions and sources of persistent organic pollutants (aliphatic hydrocarbons, PAHs, PCBs and pesticides) in surface sediments of an industrialized urban river (Huveaune), France. Science of The Total Environment 478, 141-151.

Kumar, B., Kumar, S., Sharma, C.S., 2013. Ecotoxicological Risk Assessment of Polychlorinated Biphenyls (PCBs) in Bank Sediments from along the Yamuna River in Delhi, India. Human and Ecological Risk Assessment: An International Journal 19, 1477-1487.

Laffite, A., Kilunga, P.I., Kayembe, J.M., Devarajan, N., Mulaji, C.K., Giuliani, G., Slaveykova, V.I., Poté, J., 2016. Hospital Effluents Are One of Several Sources of Metal, Antibiotic Resistance Genes, and Bacterial Markers Disseminated in SubSaharan Urban Rivers. Frontiers in Microbiology 7, 1128. 
631 Lin, C., He, M., Zhou, Y., Guo, W., Yang, Z., 2007. Distribution and contamination assessment of heavy metals in sediment of the Second Songhua River, China. Environmental Monitoring and Assessment 137, 329.

634 Li, W., Yang, H., Jiang, X., Liu, Q., Sun, Y., Zhou J.,2016. Residues and distribution of organochlorine pesticides in water and suspended particulate matter from Hangzhou Bay, East China Sea.Bull Environ Contam Toxicol. 96:295-302.

Long, E.R., 2006. Calculation and Uses of Mean Sediment Quality Guideline Quotients: A Critical Review. Environmental Science \& Technology 40, 1726-1736.

Maanan, M., Zourarah, B., Carruesco, C., Aajjane, A., Naud, J., 2004. The distribution of

MacDonald, D.D., Dipinto, L.M., Field, J., Ingersoll, C.G., Lvong, E.R., Swartz, R.C., 2000a. Development and evaluation of consensus-based sediment effect concentrations for polychlorinated biphenyls. Environmental Toxicology and Chemistry 19, 1403-1413.

MacDonald, D., Ingersoll, C., Berger, T., 2000b. Development and evaluation of consensusbased sediment quality guidelines for freshwater eco- systems. Archives of Environmental Contamination and Toxicology 39, 20-31.

Malik, R.N., Mehboob, F., Ali, U., Katsoyiannis, A., Schuster, J.K., Moeckel, C., Jones, K.C., 2014. Organo-halogenated contaminants (OHCs) in the sediments from the Soan

Manneh, R., Abi Ghanem, C., Khalaf, G., Najjar, E., El Khoury, B., Iaaly, A., El Zakhem, H., 653 2016. Analysis of polycyclic aromatic hydrocarbons (PAHs) in Lebanese surficial sediments: A focus on the regions of Tripoli, Jounieh, Dora, and Tyre. Marine Pollution Bulletin 110, 578-583. 
Mubedi, J.I., Devarajan, N., Faucheur, S.L., Mputu, J.K., Atibu, E.K., Sivalingam, P., Prabakar, K., Mpiana, P.T., Wildi, W., Poté, J., 2013. Effects of untreated hospital effluents on the accumulation of toxic metals in sediments of receiving system under tropical conditions: Case of South India and Democratic Republic of Congo. Chemosphere 93, 1070-1076.

Mwanamoki, P.M., Devarajan, N., Niane, B., Ngelinkoto, P., Thevenon, F., Nlandu, J.W., Mpiana, P.T., Prabakar, K., Mubedi, J.I., Kabele, C.G., Wildi, W., Poté, J., 2015. Trace metal distributions in the sediments from river-reservoir systems: case of the Congo River and Lake Ma Vallée, Kinshasa (Democratic Republic of Congo). Environmental Science and Pollution Research 22, 586-597.

Mwanamoki, P.M., Devarajan, N., Thevenon, F., Atibu, E.K., Tshibanda, J.B., Ngelinkoto, P., Mpiana, P.T., Prabakar, K., Mubedi, J.I., Kabele, C.G., Wildi, W., Poté, J., 2014a. Assessment of pathogenic bacteria in water and sediment from a water reservoir under tropical conditions (Lake Ma Vallée), Kinshasa Democratic Republic of Congo. Environmental Monitoring and Assessment 186, 6821-6830.

Mwanamoki, P.M., Devarajan, N., Thevenon, F., Birane, N., de Alencastro, L.F., Grandjean, D., Mpiana, P.T., Prabakar, K., Mubedi, J.I., Kabele, C.G., Wildi, W., Poté, J., 2014b. Trace metals and persistent organic pollutants in sediments from riverreservoir systems in Democratic Republic of Congo (DRC): Spatial distribution and potential ecotoxicological effects. Chemosphere 111, 485-492.

Mavakala, B. K., Le Faucheur, S., Mulaji, C. K., Laffite, A., Devarajan, N., Biey, E. M., Giuliani, G., Otamonga, J.-P., Kabatusuila, P., Mpiana, P. T., Poté, J. 2016. Leachates draining from controlled municipal solid waste landfill: Detailed geochemical characterization and toxicity tests. Waste Management. 55, 238-248. 
M.A.P.E., 2016. Pan de gestion des pestes et pesticides. Programme intégré de croissance agricole dans la région des grands lacs-projet régional. Ministère de l'agriculture, Pèche et Elevage (M.A.P.E), RDC, 67p.

Olukunle, O. I., Sibiya, I. V., Okonkwo, O. J., Odusanya, A. O., 2015. Influence of physicochemical and chemical parameters on polybrominated diphenyl ethers in selected landfill leachates, sediments and river sediments from Gauteng, South Africa. Environmental Science and Pollution Research 22, 2145-2154.

Pardos, M., Benninghoff, C., Alencastro, L.P., Wildi, W., 2004. The impact of a sewage treatment plant's effluent on sediment quality in a small bay in Lake Geneva (Switzerland-France). Part 1: Spatial distribution of contaminants and the potential for biological impacts. Lakes Reservoirs: Research and Management 9, 41-52.

Poté, J., Haller, L., Loizeau, J.-L., Garcia Bravo, A., Sastre, V., Wildi, W., 2008. Effects of a sewage treatment plant outlet pipe extension on the distribution of contaminants in the sediments of the Bay of Vidy, Lake Geneva, Switzerland. Bioresource Technology 99, 7122-7131.

Pozo, K., Harner, T., Rudolp, A et al., 2012. Survey of persistent organic pollutants (POPs) and polycyclic aromatic hydrocarbons (PAHs) in the atmosphere of rural, urban and industrial areas of Concepcion, Chile, using passive air samplers. Atmospheric Pollution Research 3, 426-434.

Raghunath, R., Tripathi, R.M., Kumar, A.V., Sathe, A.P., Khandekar, R.N., Nambi, K.S.V., 1999. Assessment of $\mathrm{Pb}, \mathrm{Cd}, \mathrm{Cu}$, and $\mathrm{Zn}$ Exposures of 6- to 10-Year-Old Children in Mumbai. Environmental Research 80, 215-221.

R Core Team (2015). R: A language and environment for statistical computing. Vienne, Austria, R Foundation for Statistical Computing. 
Sindermann, C.J., 2006. Coastal Pollution Effects on Living Resources and Humans. Taylor \& Francis Group, Boca Raton, USA.

Sakan, S.M., Đorđević, D.S., Manojlović, D.D., Predrag, P.S., 2009. Assessment of heavy metal pollutants accumulation in the Tisza river sediments. Journal of Environmental Management 90, 3382-3390.

Singh, K.P., Mohan, D., Singh, V.K., Malik, A., 2005. Studies on distribution and fractionation of heavy metals in Gomti river sediments - a tributary of the Ganges, India. Journal of Hydrology 312, 14-27.

Ssebugere, P., Sillanpää, M., Wang, P., Li, Y., Kiremire, B., Kasozi, G., Zhu, C., Ren, D., Shang, H., Zhang, Q., Jiang, G., 2014. Polychlorinated dibenzo-p-dioxins, polychlorinated dibenzofurans and polybrominated diphenyl ethers in sediments and fish species from the Murchison Bay of Lake Victoria, Uganda. Science of the Total Environment 500-501, 1-10.

Stockholm Convention, 2017. (http://chm.pops.int/default.aspx). Consulted, 2017-03-15.

Syed, J.H., Malik, R.N., Li, J., Chaemfa, C., Zhang, G., Jones, K.C., 2014. Status, distribution and ecological risk of organochlorines (OCs) in the surface sediments from the Ravi River, Pakistan. Science of The Total Environment 472, 204-211.

Tamim, U., Khan, R., Jolly, Y.N., Fatema, K., Das, S., Naher, K., Islam, M.A., Islam, S.M.A., Hossain, S.M., 2016. Elemental distribution of metals in urban river sediments near an industrial effluent source. Chemosphere 155, 509-518.

Thevenon, F., Alencastro, L.F.d., Loizeau, J.-L., Adatte, T., Grandjean, D., Wildi, W., Poté, J., 2013. A high-resolution historical sediment record of nutrients, trace elements and organochlorines (DDT and PCB) deposition in a drinking water reservoir (Lake Brêt, Switzerland) points at local and regional pollutant sources. Chemosphere 90, 24442452. 
Thevenon, F., Graham, N. D., Chiaradia, M., Arpagaus, P., Wildi, W., Poté, J., 2011. Local to regional scale industrial heavy metal pollution recorded in sediments of large freshwater lakes in Central Europe (lakes Geneva and Lucerne) over the last centuries. Science of the Total Environment, 412-413: 239-247.

Thevenon, F., Poté, J., 2012. Water Pollution History of Switzerland Recorded by Sediments of the Large and Deep Perialpine Lakes Lucerne and Geneva. Water, Air, \& Soil Pollution 223, 6157-6169.

Thevenon, F., Regier, N., Benagli, C., Tonolla, M., Adatte, T., Wildi, W., Poté, J., 2012. Characterization of fecal indicator bacteria in sediments cores from the largest freshwater lake of Western Europe (Lake Geneva, Switzerland). Ecotoxicology and Environmental Safety 78, 50-56.

Tshibanda, J.B., Devarajan, N., Birane, N., Mwanamoki, P.M., Atibu, E.K., Mpiana, P.T., Prabakar, K., Mubedi Ilunga, J., Wildi, W., Poté, J., 2014. Microbiological and physicochemical characterization of water and sediment of an urban river: N'Djili River, Kinshasa, Democratic Republic of the Congo. Sustainability of Water Quality and Ecology 3-4, 47-54.

UNEP-POPs, 2012. (http://www.chem.unep.ch/Pops/GMP/default.htm). Consulted 23.10.12.

Varol, M., 2011. Assessment of heavy metal contamination in sediments of the Tigris River (Turkey) using pollution indices and multivariate statistical techniques. Journal of Hazardous Materials 195, 355-364.

Verhaert, V., Covaci, A., Bouillon, S., Abrantes, K., Musibono, D., Bervoets, L., Verheyen, E., Blust, R., 2013. Baseline levels and trophic transfer of persistent organic pollutants in sediments and biota from the Congo River Basin (DR Congo). Environment International 59, 290-302. 
753 Wildi, W., Dominik, J., Loizeau, J.-L., Thomas, R.L., Favarger, P.-Y., Haller, L., Perroud, A.,

754

755

756

757

758

759

760

761

762

763

764

765

766

767

768 Peytremann, C., 2004. River, reservoir and lake sediment contamination by heavy metals downstream from urban areas of Switzerland. Lakes \& Reservoirs: Research \& Management 9, 75-87.

WHO, World Health Organisation.World Malaria Report 2011. Country profile, Democratic Republic of Congo; 2011110.

Yang, Y., Woodward, L.A., Li, Q.X., Wang, J., 2014. Concentrations, Source and Risk Assessment of Polycyclic Aromatic Hydrocarbons in Soils from Midway Atoll, North Pacific Ocean. PLOS ONE 9, e86441.

Yunker, M.B., Macdonald, R.W., Vingarzan, R., Mitchell, R.H., Goyette, D., Sylvestre, S., 2002. PAHs in the Fraser River basin: a critical appraisal of PAH ratios as indicators of PAH source and composition. Organic Geochemistry 33, 489-515.

Zhang, J., Liu, C.L., 2002. Riverine Composition and Estuarine Geochemistry of Particulate Metals in China-Weathering Features, Anthropogenic Impact and Chemical Fluxes. Estuarine, Coastal and Shelf Science 54, 1051-1070.

Zhang, Y., Guo, C.-S., Xu, J., Tian, Y.-Z., Shi, G.-L., Feng, Y.-C., 2012. Potential source contributions and risk assessment of PAHs in sediments from Taihu Lake, China: Comparison of three receptor models. Water Research 46, 3065-3073. 
774 Tables

775 Table 1. GPS location of sampling sites and physico-chemical parameters of surface

776 sediments from Makelele, Kalamu and Nsanga Rivers

777

\begin{tabular}{|c|c|c|c|c|c|c|c|c|c|c|c|}
\hline site & Sample & Longitude & Latitude & $\begin{array}{l}\mathrm{OM} \\
(\%)\end{array}$ & $\begin{array}{c}\text { Median } \\
\text { grain size } \\
(\mu \mathrm{m})\end{array}$ & $\begin{array}{l}\text { Clay } \\
(\%) \\
\end{array}$ & $\begin{array}{l}\text { Silt } \\
(\%)\end{array}$ & $\begin{array}{c}\text { Sand } \\
(\%)\end{array}$ & $\begin{array}{l}\mathrm{TC} \\
(\%) \\
\end{array}$ & $\begin{array}{c}\mathrm{TN} \\
\left(\mathrm{mg} \mathrm{kg}^{-1}\right) \\
\end{array}$ & $\begin{array}{c}\mathrm{TP} \\
\left(\mathrm{mg} \mathrm{kg}^{-1}\right)\end{array}$ \\
\hline \multirow{2}{*}{$\mathrm{R} 1$} & $\mathrm{R} 1 \mathrm{~A}$ & $15^{\circ} 16^{\prime} 28.0^{\prime \prime}$ & $4^{\circ} 19^{\prime} 95^{\prime \prime}$ & 9.15 & 105.3 & 2.06 & 29.7 & 68.24 & 1.65 & 2.56 & 141.80 \\
\hline & R1B & $15^{\circ} 16^{\prime} 24.5^{\prime \prime}$ & $4^{\circ} 19^{\prime} 89^{\prime \prime}$ & 5.26 & 101.8 & 2.08 & 21.28 & 76.64 & 2.80 & 3.04 & 92.60 \\
\hline \multirow{4}{*}{$\mathrm{R} 2$} & $\mathrm{R} 1 \mathrm{C}$ & $15^{\circ} 16^{\prime} 29.2^{\prime \prime}$ & $4^{\circ} 19^{\prime} 94.7^{\prime \prime}$ & 8.05 & 46.77 & 4.08 & 48.02 & 47.90 & 4.79 & 6.32 & 242.74 \\
\hline & $\mathrm{R} 2 \mathrm{~A}$ & $15^{\circ} 19^{\prime} 38.0 ’$ & $4^{\circ} 21^{\prime} 08.0^{\prime \prime}$ & 7.19 & 191.6 & 0.60 & 12.78 & 86.62 & 2.10 & 3.08 & 98.60 \\
\hline & $\mathrm{R} 2 \mathrm{~B}$ & $15^{\circ} 19^{\prime} 37.0^{\prime \prime}$ & $4^{\circ} 21^{\prime} 11.2$ ', & 12.64 & 32.85 & 2.64 & 68.16 & 29.2 & 3.62 & 2.80 & 76.49 \\
\hline & $\mathrm{R} 2 \mathrm{C}$ & $15^{\circ} 19^{\prime} 37.3^{\prime \prime}$ & $4^{\circ} 21^{\prime} 08.1$ ', & 7.95 & 195.9 & 0.27 & 9.07 & 90.6 & 7.20 & 3.20 & 133.60 \\
\hline \multirow{3}{*}{ R3 } & R2D & $15^{\circ} 19^{\prime} 37.1^{\prime \prime}$ & $4^{\circ} 21^{\prime} 06.8^{\prime \prime}$ & 11.38 & 50.87 & 0.74 & 52.52 & 46.74 & 2.50 & 3.60 & 163.23 \\
\hline & R3A & $15^{\circ} 22^{\prime} 49.6^{\prime \prime}$ & $4^{\circ} 23^{\prime} 23.4^{\prime \prime}$ & 1.73 & 225.30 & 1.50 & 6.69 & 91.81 & 1.72 & 4.20 & 89.75 \\
\hline & R3B & $15^{\circ} 22^{\prime} 49.2^{\prime \prime}$ & $4^{\circ} 23^{\prime} 23.9^{\prime \prime}$ & 13.35 & 79.53 & 0.80 & 40.76 & 58.44 & 2.37 & 1.78 & 67.40 \\
\hline
\end{tabular}

778 R1, R2, R3: Makelele, Kalamu, Nsanga Rivers, respectively. MO: total organic matter, TC:

779 total carbon, TN: total nitrogen, TP: total phosphorus

780

781

782

783 
784 Table 2. Metal content of surface sediment samples from River Makelele (R1), Kalamu (R2)

785 and Nsanga (R3) analyzed by ICP-MS ${ }^{\mathrm{a}}$

Concentration $\left(\mathrm{mg}^{\mathrm{kg}} \mathrm{kg}^{-1}\right)$

\begin{tabular}{|c|c|c|c|c|c|c|c|c|c|c|c|c|c|c|c|}
\hline \multicolumn{16}{|c|}{ Concentration (mg.kg $\left.{ }^{-1}\right)$} \\
\hline $\begin{array}{c}\text { Sampling } \\
\text { sites }\end{array}$ & $\begin{array}{l}\text { Sample } \\
\text { number }\end{array}$ & $\mathrm{Sc}$ & $\mathrm{Ti}$ & $\mathrm{Cr}$ & Co & $\mathrm{Ni}$ & $\mathrm{Cu}$ & $\mathrm{Zn}$ & As & Mo & $\mathrm{Ag}$ & $\mathrm{Cd}$ & $\mathrm{Sn}$ & $\mathrm{Sb}$ & $\mathrm{Pb}$ \\
\hline Makelele & $\mathrm{R} 1 \mathrm{~A}$ & 0.71 & 63.93 & 12.57 & 0.96 & 3.94 & 31.68 & 177.15 & 1.03 & 0.32 & 0.10 & 0.76 & 1.89 & 0.20 & 38.03 \\
\hline \multirow{5}{*}{ Kalamu } & R1B & 0.37 & 41.67 & 8.43 & 0.71 & 2.01 & 18.19 & 128.10 & 0.49 & 0.08 & 0.07 & 0.23 & 0.49 & 0.22 & 37.80 \\
\hline & $\mathrm{R} 1 \mathrm{C}$ & 1.30 & 98.89 & 28.51 & 3.93 & 9.80 & 71.91 & 549.64 & 1.64 & 0.22 & 0.31 & 1.26 & 1.61 & 0.32 & 132.29 \\
\hline & $\mathrm{R} 2 \mathrm{~A}$ & 0.22 & 49.67 & 6.67 & 1.27 & 2.95 & 23.52 & 304.68 & 0.83 & 0.00 & 0.69 & 1.13 & 0.97 & 0.60 & 64.49 \\
\hline & $\mathrm{R} 2 \mathrm{~B}$ & 0.26 & 54.31 & 10.14 & 1.30 & 4.04 & 39.79 & 333.54 & 0.65 & 0.06 & 0.21 & 0.86 & 0.60 & 0.77 & 71.20 \\
\hline & $\mathrm{R} 2 \mathrm{C}$ & 0.12 & 30.55 & 4.77 & 0.68 & 2.27 & 33.04 & 177.62 & 0.44 & n.a & 0.07 & 0.41 & 0.57 & 0.69 & 65.83 \\
\hline \multirow[b]{2}{*}{ Nsanga } & $\mathrm{R} 2 \mathrm{~A}$ & 0.21 & 50.67 & 8.45 & 1.24 & 4.33 & $\mathbf{3 7 . 5 5}$ & 286.76 & 0.55 & 0.13 & 0.23 & 0.78 & 0.88 & 0.66 & 64.57 \\
\hline & $\begin{array}{l}\text { R3A } \\
\text { R3B }\end{array}$ & $\begin{array}{l}0.12 \\
0.18\end{array}$ & $\begin{array}{l}26.36 \\
53.38 \\
\end{array}$ & $\begin{array}{c}7.51 \\
14.01\end{array}$ & $\begin{array}{l}0.53 \\
1.41 \\
\end{array}$ & $\begin{array}{l}11.18 \\
16.94 \\
\end{array}$ & $\begin{array}{l}213.03 \\
325.14\end{array}$ & $\begin{array}{l}130.17 \\
396.72\end{array}$ & $\begin{array}{l}0.29 \\
0.88\end{array}$ & $\begin{array}{l}0.17 \\
0.54\end{array}$ & $\begin{array}{l}0.32 \\
0.54\end{array}$ & $\begin{array}{l}0.48 \\
\mathbf{1 . 5 4}\end{array}$ & $\begin{array}{l}1.47 \\
1.98\end{array}$ & $\begin{array}{l}0.49 \\
1.47 \\
\end{array}$ & $\begin{array}{c}24.59 \\
\mathbf{1 6 5 . 3 0}\end{array}$ \\
\hline $\operatorname{Rec}^{\mathrm{b}} . \max$ & & & & 37.30 & & & 35.70 & 123.00 & 5.90 & & & 0.60 & & & 35.00 \\
\hline LKSD 4 & & & & 21 & 11 & 32 & 30 & 189 & & 2 & 0.2 & 1.9 & & 1.5 & 93 \\
\hline
\end{tabular}

${ }^{a}$ Total variation coefficients for triplicate measurements are smaller than $5 \%$ for ICP-MS analysis. The recovery values from the ICP-MS triplicate measurements for reference material (LKSD 4) was above $97.5 \%$ for all elements.

${ }^{\mathrm{b}}$ Canadian Sediment Quality Guidelines for the Protection of Aquatic Life recommendation. In bold represent the concentration of the heavy metals above the recommended concentration according to the Canadian Sediment Quality Guidelines for the Protection of Aquatic Life recommendation (CCME EPC-98E 1999).

794 n.a - analysis not performed. 
800 Table 3. Igeo and $\mathrm{EF}$ values for $\mathrm{Cu}, \mathrm{Zn}$ and $\mathrm{Pb}$ in surface sediments.

\begin{tabular}{|c|c|c|c|c|c|c|c|}
\hline & & \multicolumn{3}{|c|}{ Igeo } & \multicolumn{3}{|c|}{ EF } \\
\hline $\begin{array}{l}\text { Sampling } \\
\text { sites }\end{array}$ & Sample number & $\mathrm{Cu}$ & $\mathrm{Zn}$ & $\mathrm{Pb}$ & $\mathrm{Cu}$ & $\mathrm{Zn}$ & $\mathrm{Pb}$ \\
\hline \multirow{3}{*}{ Makelele } & $\mathrm{R} 1 \mathrm{~A}$ & -1.16 & 3.67 & 2.62 & 3.12 & 88.43 & 42.78 \\
\hline & R1B & -0.40 & 3.80 & 2.76 & 4.35 & 79.69 & 38.88 \\
\hline & $\mathrm{R} 1 \mathrm{C}$ & -0.67 & 2.89 & 2.65 & 7.87 & 92.49 & 78.35 \\
\hline \multirow{4}{*}{ Kalamu } & $\mathrm{R} 2 \mathrm{~A}$ & -0.48 & 3.58 & 2.62 & 5.08 & 84.80 & 43.64 \\
\hline & $\mathrm{R} 2 \mathrm{~B}$ & 2.02 & 2.44 & 1.23 & 51.15 & 68.38 & 29.52 \\
\hline & $\mathrm{R} 2 \mathrm{C}$ & 2.63 & 4.05 & 3.98 & 50.68 & 135.26 & 128.81 \\
\hline & $\mathrm{R} 2 \mathrm{D}$ & -0.73 & 2.88 & 1.86 & 1.28 & 15.70 & 7.70 \\
\hline \multirow{2}{*}{ Nsanga } & R3A & -1.53 & 2.42 & 1.85 & 1.40 & 21.62 & 14.58 \\
\hline & R3B & 0.45 & 4.52 & 3.66 & 1.58 & 26.44 & 14.54 \\
\hline
\end{tabular}

801

802

\begin{tabular}{|c|c|c|c|}
\hline $\operatorname{Igeo} \leq 0$ & Class 0 - practically unpolluted & $\mathrm{EF}<1$ & no enrichment \\
\hline $0<\operatorname{Igeo}<1$ & Class 1 - unpolluted to moderately polluted & $\mathrm{EF}<3$ & minor enrichment \\
\hline $1<\operatorname{Igeo}<2$ & Class 2 - moderately polluted & EF $3-5$ & moderate enrichment \\
\hline $2<\operatorname{Igeo}<3$ & Class 3 - moderately to heavily polluted & EF $5-10$ & moderately severe enrichment \\
\hline $3<$ Igeo $<4$ & Class 4 - heavily polluted & EF $10-25$ & severe enrichment \\
\hline $4<\operatorname{Ig} e$ & Class 5 - heavily to extremely polluted & EF $25-50$ & very severe enrichment \\
\hline $5>$ Igeo & Class 6 - extremely polluted & $\mathrm{EF}>50$ & extremely severe enrichment \\
\hline
\end{tabular}

803

804

805

806

807

808

809

810

811

812

813

814 
815 Table 4a. Concentration (in $\mu \mathrm{g} \mathrm{kg}{ }^{-1}$ dry weight) of polychlorinated biphenyl (PCBs), and 816 polycyclic aromatic hydrocarbons (PAHs) in sediment samples from River Makelele (R1), 817 Kalamu (R2) and Nsanga (R3).

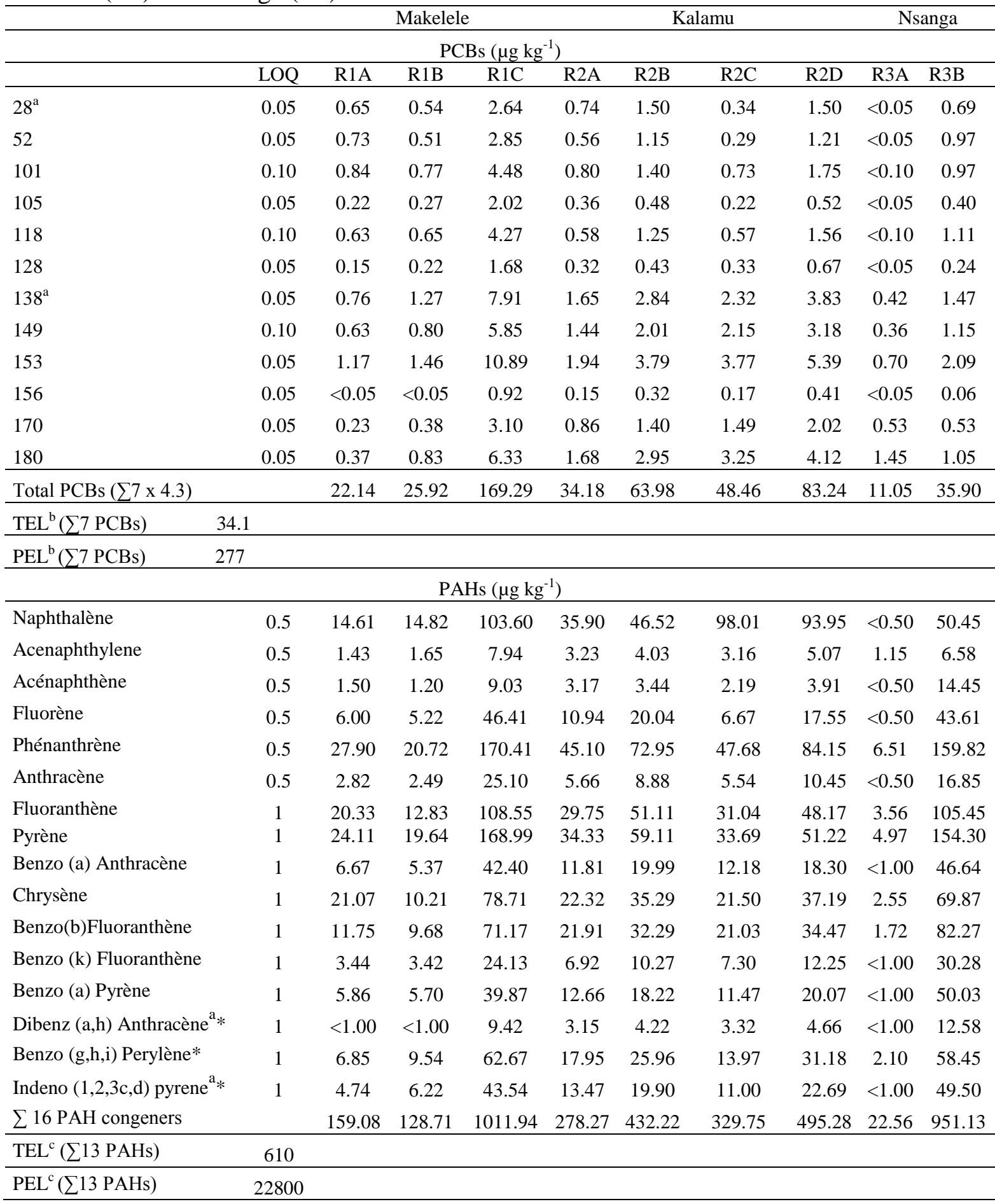

${ }^{\mathrm{a}}$ Chromatographic separation on a ZB-XLB column. All remaining compounds on a ZB-5ms column.

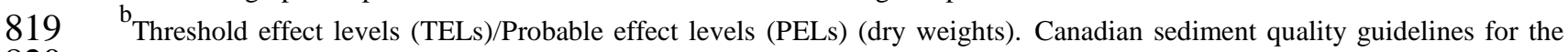
820 protection of aquatic life. Canadian Council of Ministers of the Environment. (CCME, 2002).

$821{ }^{\mathrm{c}}$ MacDonald et al 2000b. Development and evaluation of consensus-based sediment quality guidelines for freshwater eco-

823 *Not included in the sum of ( $\sum 13$ PAHs) TEL and PEL values 
825 Table 4b. Concentration (in $\mu \mathrm{g} \mathrm{kg}-1$ dry weight) of organochlorine pesticides (OCPs) and 826 BDEs in sediment samples from river Makelele (R1), Kalamu (R2) and Nsanga (R3)

\begin{tabular}{|c|c|c|c|c|c|c|c|c|c|c|c|}
\hline & \multicolumn{5}{|c|}{ Makelele } & \multicolumn{2}{|c|}{ Kalamu } & \multicolumn{3}{|c|}{ Nsanga } & \multirow[t]{2}{*}{$\operatorname{Rec}^{\mathrm{a}}$} \\
\hline \multicolumn{11}{|c|}{ OCPs $\left(\mu \mathrm{g} \mathrm{kg}^{-1}\right)$} & \\
\hline & LOQ & R1A & R1B & R1C & $\mathrm{R} 2 \mathrm{~A}$ & $\mathrm{R} 2 \mathrm{~B}$ & $\mathrm{R} 2 \mathrm{C}$ & $\mathrm{R} 2 \mathrm{D}$ & R3A & $\mathrm{R} 3 \mathrm{~B}$ & \\
\hline hexachlorobenzène & 0.05 & $<0.05$ & 0.40 & 1.44 & $<0.05$ & 0.09 & $<0.05$ & 0.23 & 0.10 & $<0.05$ & \\
\hline alpha-HCH & 0.10 & $<0.10$ & $<0.10$ & $<0.10$ & $<0.10$ & $<0.10$ & $<0.10$ & $<0.10$ & $<0.10$ & $<0.10$ & \\
\hline beta-HCH & 0.05 & 0.10 & $<0.05$ & 0.14 & $<0.05$ & $<0.05$ & 0.12 & $<0.05$ & $<0.05$ & $<0.05$ & \\
\hline gamma-HCH & 0.10 & 0.26 & 0.17 & 0.44 & $<0.10$ & 0.12 & 0.43 & $<0.10$ & $<0.10$ & $<0.10$ & \\
\hline delta-HCH & 0.30 & $<0.30$ & $<0.30$ & $<0.30$ & $<0.30$ & $<0.30$ & $<0.30$ & $<0.30$ & $<0.30$ & $<0.30$ & \\
\hline chlorpyrifos-methyl $^{c}$ & 1.00 & $<1.00$ & $<1.00$ & $<1.00$ & $<1.00$ & $<1.00$ & $<1.00$ & $<1.00$ & $<1.00$ & $<1.00$ & \\
\hline chlorpyrifos-ethyl $^{\mathrm{c}}$ & 0.50 & 1.95 & 2.30 & 16.98 & 1.86 & 3.68 & 1.55 & 1.82 & $<0.50$ & 3.36 & \\
\hline gamma-chlordane & 0.30 & $<0.30$ & $<0.30$ & $<0.30$ & $<0.30$ & $<0.30$ & $<0.30$ & $<0.30$ & $<0.30$ & $<0.30$ & \\
\hline alpha-chlordane & 0.30 & $<0.30$ & $<0.30$ & $<0.30$ & $<0.30$ & $<0.30$ & $<0.30$ & $<0.30$ & $<0.30$ & $<0.30$ & \\
\hline dieldrin & 0.30 & $<0.30$ & $<0.30$ & $<0.30$ & $<0.30$ & $<0.30$ & $<0.30$ & $<0.30$ & $<0.30$ & $<0.30$ & \\
\hline endrin & 0.50 & $<0.50$ & $<0.50$ & $<0.50$ & $<0.50$ & $<0.50$ & $<0.50$ & $<0.50$ & $<0.50$ & $<0.50$ & \\
\hline heptachlor & 0.10 & $<0.10$ & $<0.10$ & $<0.10$ & $<0.10$ & $<0.10$ & $<0.10$ & $<0.10$ & $<0.10$ & $<0.10$ & \\
\hline aldrin $^{c}$ & 0.10 & $<0.10$ & $<0.10$ & $<0.10$ & $<0.10$ & $<0.10$ & $<0.10$ & $<0.10$ & $<0.10$ & $<0.10$ & \\
\hline heptachlor epoxid A & 0.30 & $<0.30$ & $<0.30$ & $<0.30$ & $<0.30$ & $<0.30$ & $<0.30$ & $<0.30$ & $<0.30$ & $<0.30$ & \\
\hline heptachlor epoxid B & 0.30 & $<0.30$ & $<0.30$ & $<0.30$ & $<0.30$ & $<0.30$ & $<0.30$ & $<0.30$ & $<0.30$ & $<0.30$ & \\
\hline endosulfan I & 1.00 & $<1.00$ & $<1.00$ & $<1.00$ & $<1.00$ & $<1.00$ & $<1.00$ & $<1.00$ & $<1.00$ & $<1.00$ & \\
\hline endosulfan II & 1.00 & $<1.00$ & $<1.00$ & $<1.00$ & $<1.00$ & $<1.00$ & $<1.00$ & $<1.00$ & $<1.00$ & $<1.00$ & \\
\hline endosulfan sulfate & 0.50 & $<0.50$ & $<0.50$ & $<0.50$ & $<0.50$ & $<0.50$ & $<0.50$ & $<0.50$ & $<0.50$ & $<0.50$ & \\
\hline endrin aldehyde & 0.50 & $<0.50$ & $<0.50$ & $<0.50$ & $<0.50$ & $<0.50$ & $<0.50$ & $<0.50$ & $<0.50$ & $<0.50$ & \\
\hline endrin ketone & 0.50 & $<0.50$ & $<0.50$ & $<0.50$ & $<0.50$ & $<0.50$ & $<0.50$ & $<0.50$ & $<0.50$ & $<0.50$ & \\
\hline methoxychlor & 0.30 & $<0.30$ & $<0.30$ & $<0.30$ & $<0.30$ & $<0.30$ & $<0.30$ & $<0.30$ & $<0.30$ & $<0.30$ & \\
\hline acetochlor $^{\mathrm{c}}$ & 1.00 & $<1.00$ & $<1.00$ & $<1.00$ & $<1.00$ & $<1.00$ & $<1.00$ & $<1.00$ & $<1.00$ & $<1.00$ & \\
\hline oxy-chlordane ${ }^{c}$ & 0.30 & $<0.30$ & $<0.30$ & $<0.30$ & $<0.30$ & $<0.30$ & $<0.30$ & $<0.30$ & $<0.30$ & $<0.30$ & \\
\hline trans-nonachlor & 0.10 & $<0.10$ & $<0.10$ & 0.20 & $<0.10$ & $<0.10$ & $<0.10$ & $<0.10$ & $<0.10$ & $<0.10$ & \\
\hline mirex & 0.30 & $<0.30$ & $<0.30$ & $<0.30$ & $<0.30$ & $<0.30$ & $<0.30$ & $<0.30$ & $<0.30$ & $<0.30$ & \\
\hline cyhalothrin- $\lambda$ (lambda) & 1.00 & 2.67 & 1.71 & 12.42 & 2.29 & 3.33 & $<1.00$ & $<1.00$ & $<1.00$ & $<1.00$ & \\
\hline cypermethrin a & 5.00 & 13.84 & $<5.00$ & 31.12 & 10.85 & 8.17 & $<5.00$ & $<5.00$ & $<5.00$ & 34.95 & \\
\hline cypermethrin b & 7.00 & 16.61 & $<7.00$ & 20.80 & $<7.00$ & $<7.00$ & $<7.00$ & $<7.00$ & $<7.00$ & $<7.00$ & \\
\hline deltamethrin & 7.00 & 43.83 & 27.31 & 227.48 & 42.68 & 97.33 & 43.83 & 32.17 & 12.49 & 69.14 & \\
\hline \multicolumn{12}{|c|}{ DDTs $\left(\mu \mathrm{g} \mathrm{kg}^{-1}\right)$} \\
\hline $\mathrm{p}, \mathrm{p}^{\prime}-\mathrm{DDE}$ & 0.10 & 146.75 & 9.57 & 63.71 & 9.54 & 15.92 & 11.03 & 20.99 & 0.66 & 9.97 & \\
\hline o,p'-DDE & 0.10 & 7.51 & 0.26 & 1.72 & 0.23 & 0.40 & 0.33 & 0.46 & $<0.10$ & 0.18 & \\
\hline p,p'-DDD & 0.10 & 21.57 & 5.10 & 39.40 & 5.84 & 10.15 & 4.95 & 12.79 & 0.21 & 4.86 & \\
\hline$o, p^{\prime}-D_{D D}{ }^{c}$ & 0.10 & 22.03 & 1.47 & 9.18 & 1.56 & 2.59 & 1.81 & 3.62 & $<0.10$ & 1.33 & \\
\hline p,p'-DDT & 0.10 & 29.17 & 4.79 & 17.14 & 6.49 & 2.70 & 3.73 & 3.41 & 0.27 & 3.09 & \\
\hline$o, p^{\prime}-\mathrm{DDT}^{\mathrm{c}}$ & 0.10 & 43.58 & 0.56 & 1.47 & 1.05 & 0.55 & 0.78 & 0.81 & 0.09 & 0.82 & \\
\hline$\sum 6$ pesticides & & 270.61 & 21.75 & 132.62 & 24.71 & 32.31 & 22.63 & 42.08 & 1.23 & 20.25 & \\
\hline TEL $^{\mathrm{b}}\left(\sum 6 \mathrm{DDTs}\right)$ & 6.15 & & & & & & & & & & \\
\hline 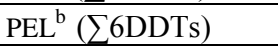 & 20.03 & & & & & & & & & & \\
\hline \multicolumn{12}{|c|}{$\operatorname{PBDE}\left(\mu \mathrm{g} \mathrm{kg}^{-1}\right)$} \\
\hline BDE28 & 0.15 & $<0.15$ & $<0.15$ & $<0.15$ & $<0.15$ & $<0.15$ & $<0.15$ & $<0.15$ & $<0.15$ & $<0.15$ & 44 \\
\hline BDE47 & 0.10 & 1.80 & 0.55 & 4.24 & 1.21 & 1.93 & 0.83 & 2.27 & 1.32 & 8.66 & 39 \\
\hline BDE100 & 0.10 & 0.54 & 0.18 & 1.17 & 0.40 & 0.54 & 0.28 & 0.75 & 0.51 & 2.95 & 0.4 \\
\hline BDE99 & 0.10 & 2.23 & 0.75 & 5.87 & 1.27 & 2.16 & 0.97 & 2.55 & 1.79 & 12.88 & 0.4 \\
\hline BDE154 & 0.15 & 0.29 & $<0.15$ & 0.69 & $<0.15$ & 0.42 & $<0.15$ & 0.36 & 0.28 & 1.48 & 440 \\
\hline BDE153 & 0.15 & $<0.15$ & $<0.15$ & 0.92 & $<0.15$ & 0.50 & $<0.15$ & 0.55 & $<0.15$ & 1.98 & 440 \\
\hline$\sum 6$ PBDEs & & 4.86 & 1.48 & 12.90 & 2.88 & 5.55 & 2.09 & 6.48 & 3.90 & 27.95 & \\
\hline
\end{tabular}

827 The values in bold represent the concentration of the PBDEs above the recommended concentration according to the

828 Canadian Federal Environmental quality guidelines Polybrominated Diphenyl Ethers (PBDEs). (Canadian Environmental 829 Protection Act, 1999.

$830 \mathrm{Rec}^{\mathrm{a}}$. Federal Environmental quality guidelines Polybrominated Diphenyl Ethers (PBDEs) in sediments. $831<$ Lttps://www.ec.gc.ca/ese-ees/>

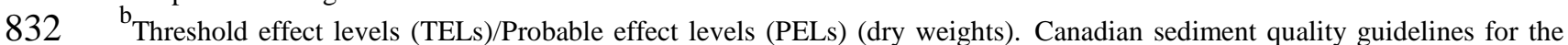
833 protection of aquatic life. Canadian Council of Ministers of the Environment. (CCME, 2002).

$834{ }^{\mathrm{c}}$ Chromatographic separation on a ZB-XLB column. All remaining compounds on a ZB-5ms column. 
835 Table 5. The values of Fluo/ (Fluo + Pyr), IDP/ (IDP + BghiP), BaA/ (BaA + Chry), and 836 LMW/HMW ratios.

837

838

839

840

841

842

843

844

845

846

847

848

849

850

851

852

853

854

855

856

857

\section{0}

\begin{tabular}{|l|l|l|l|}
\hline & Makelele & Kalamu & Nsanga \\
\hline Fluo/ (Fluo + Pyr) & $0.39-0.46$ & $0.46-0.48$ & $0.41-0.42$ \\
\hline IDP/ (IDP + BghiP) & $0.39-0.41$ & $0.42-0.44$ & *NA-0.46 \\
\hline BaA/ (BaA + Chry) & $0.24-0.35$ & $0.33-0.36$ & NA-0.40 \\
\hline **LMW/HMW & $0.52-0.56$ & $0.56-0.98$ & $0.44-0.51$ \\
\hline
\end{tabular}

* Not available due to the concentration of individual PAH compound being below the Limit of quantification.

**LMW/HMW: Ratio of low molecular weight (LMW) PAHs (i.e. Naphthalene (Naph), Acenaphthylene (Acy), Acenaphthene (Ace), Fluorene (Fl), Phenanthrene (Phen), Anthracene (Anthr) to high molecular weight (HMW) PAHs (i.e. fluoranthene (Fluo), pyrene (Pyr), benzo[a]anthracene $(\mathrm{BaA})$, chrysene (Chry), benzo[b]fluoranthene $(\mathrm{BbF})$, benzo[k]fluoranthene $(\mathrm{BkF})$, benzo[a]pyrene $(\mathrm{BaP})$, indeno[1,2,3-cd]pyrene (IDP), dibenz[a,h]anthracene (DahA) , and benzo[g,h,i]perylene (BghiP). (1) 
858 Table 6. Spearman's rank-order correlation of selected parameters ${ }^{\mathrm{a}}$ analyzed in the surface 859 sediments

860

\begin{tabular}{|c|c|c|c|c|c|c|c|c|c|c|c|c|}
\hline & $\mathrm{Zn}$ & $\mathrm{Cd}$ & $\mathrm{Pb}$ & TOM & $\begin{array}{c}\text { Grain } \\
\text { size }\end{array}$ & $\mathrm{TC}$ & $\mathrm{TN}$ & TP & PCBs & PAHs & DDTs & PBDEs \\
\hline $\mathrm{Cu}$ & 0.517 & 0.533 & 0.500 & 0.00 & 0.0833 & -0.350 & -0.0667 & -0.250 & -0.050 & 0.100 & -0.333 & 0.183 \\
\hline $\mathrm{Zn}$ & & 0.917 & 0.900 & -0.283 & 0.117 & -0.467 & 0.183 & 0.367 & -0.167 & -0.300 & 0.267 & -0.183 \\
\hline $\mathrm{Cd}$ & & & 0.733 & -0.167 & 0.250 & -0.667 & -0.117 & 0.117 & -0.350 & -0.400 & 0.200 & -0.200 \\
\hline $\mathrm{Pb}$ & & & & -0.467 & 0.150 & -0.183 & 0.467 & 0.467 & 0.0167 & -0.200 & 0.233 & -0.267 \\
\hline TOM & & & & & -0.633 & 0.117 & -0.517 & -0.117 & 0.533 & 0.733 & 0.367 & 0.767 \\
\hline Grain size & & & & & & -0.367 & 0.0333 & -0.0167 & -0.633 & -0.617 & -0.350 & -0.667 \\
\hline $\mathrm{TC}$ & & & & & & & 0.300 & 0.183 & 0.733 & 0.500 & 0.0667 & -0.0333 \\
\hline $\mathrm{TN}$ & & & & & & & & 0.567 & 0.3 & 0.050 & 0.050 & -0.0667 \\
\hline $\mathrm{TP}$ & & & & & & & & & 0.4 & 0.233 & 0.733 & 0.0333 \\
\hline PCBs & & & & & & & & & & 0.883 & 0.450 & 0.517 \\
\hline PAHs & & & & & & & & & & & 0.367 & 0.783 \\
\hline DDTs & & & & & & & & & & & & 0.283 \\
\hline
\end{tabular}

861

862 a Parameters include toxic metals, median grain size, total organic matter, TC, TN, TP, 863 PCBs, PAHs, DDTs and PBDEs $[n=9$, statistically significant coefficients $(p<0.05)$ are in 864 bold.

865

866

867

868

869

870

871

872

873

874

875 


\section{Figure caption}

877 Figure 1. Location map of the study area. A: Location Map of Congo DR in Africa. B: Map of 878 Congo DR. C: Location map of studied Rivers, R1: Makelele, R2: Kalamu, R3: Nsanga at 879 Kinshasa, Congo DR.

880

881

882

883

884

885

886
Figure 2. Score plot for principal component analysis (PCA) applied to sediment mesurement across sampling sites: (a) PCA of PCBs congeners, (b) PCA of pesticides congeners, (c) PCA of PBDEs congeners and (d) PCA of PAHs congeners 
Fig. 1.

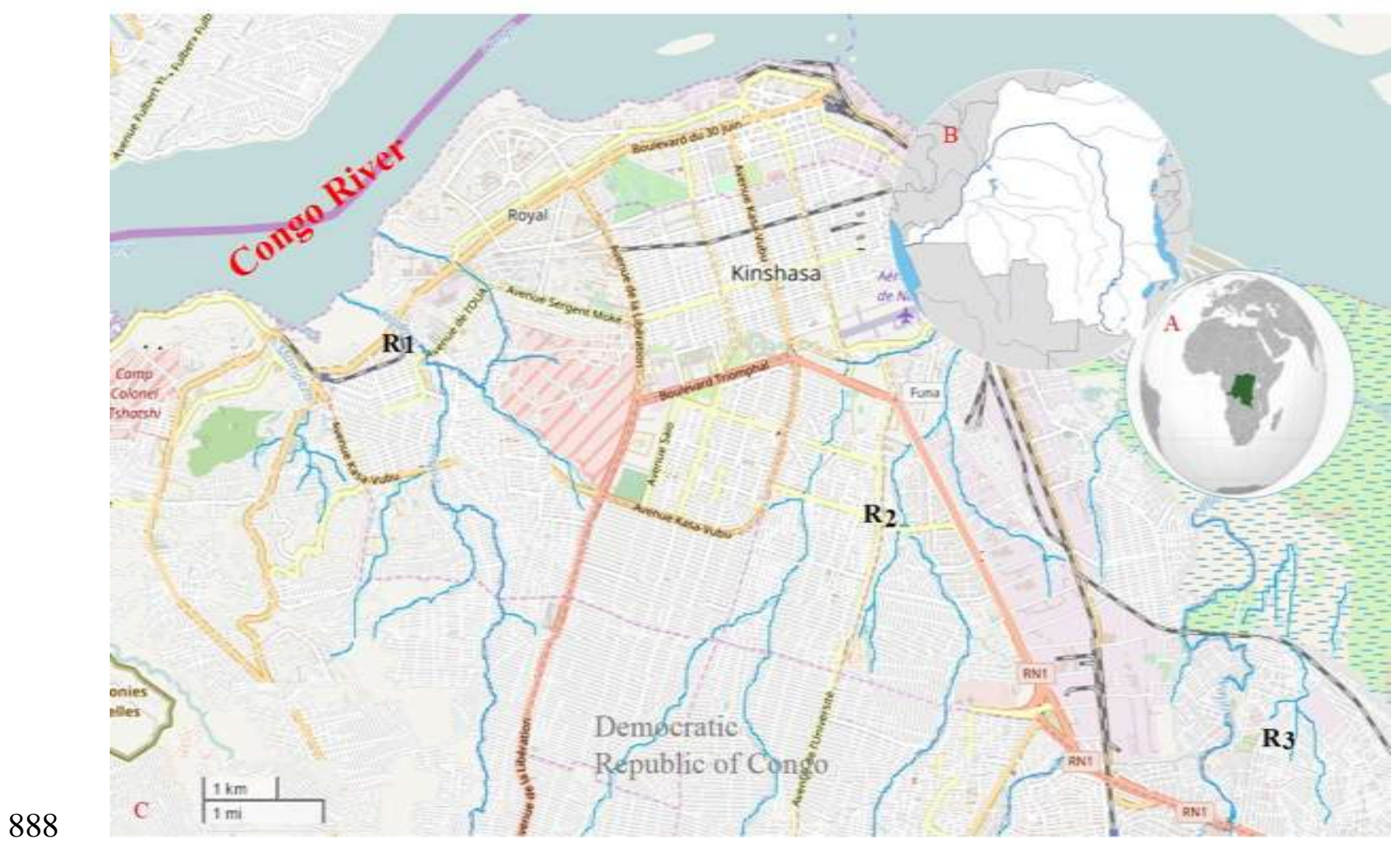


Fig. 2.

891
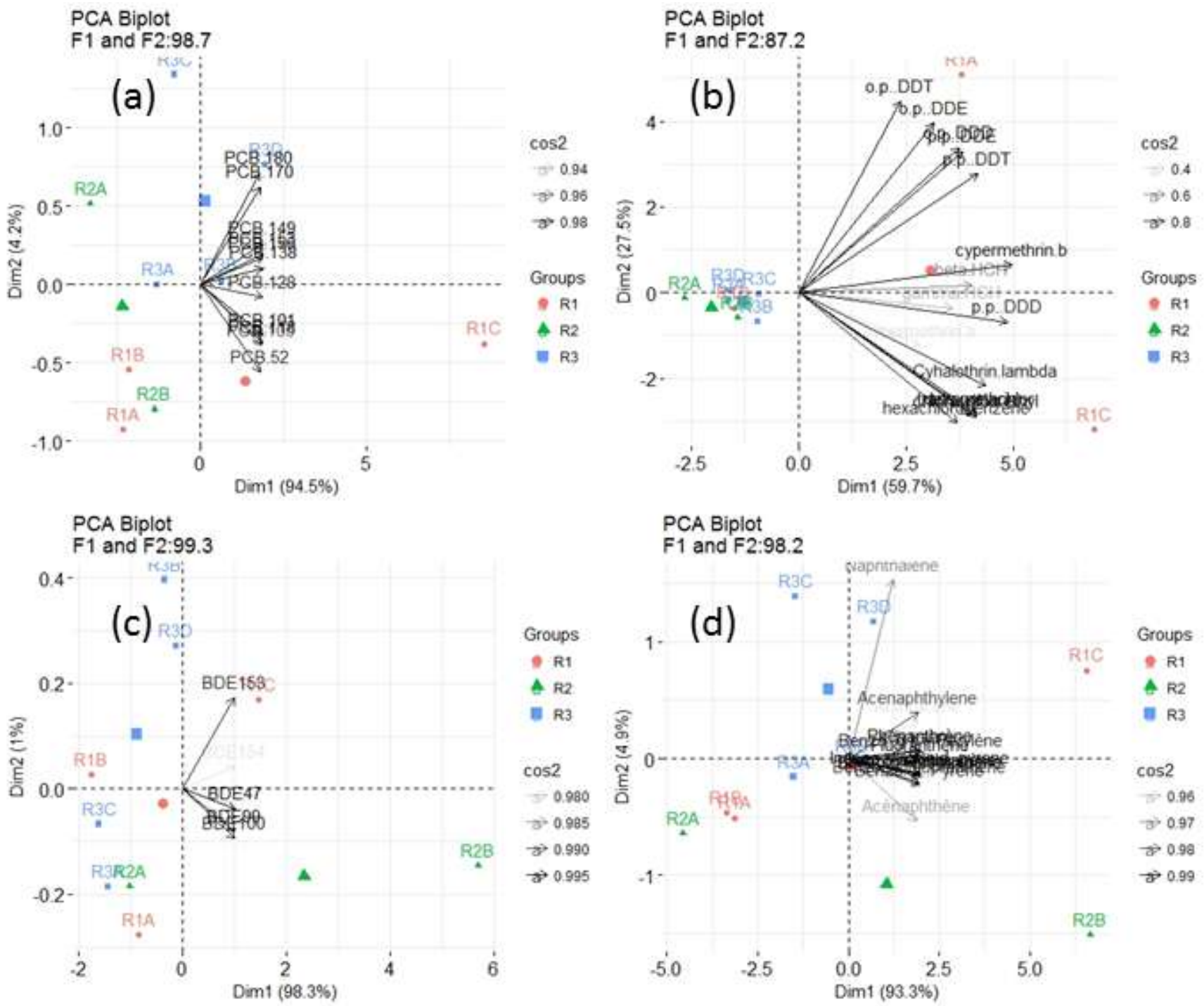

892
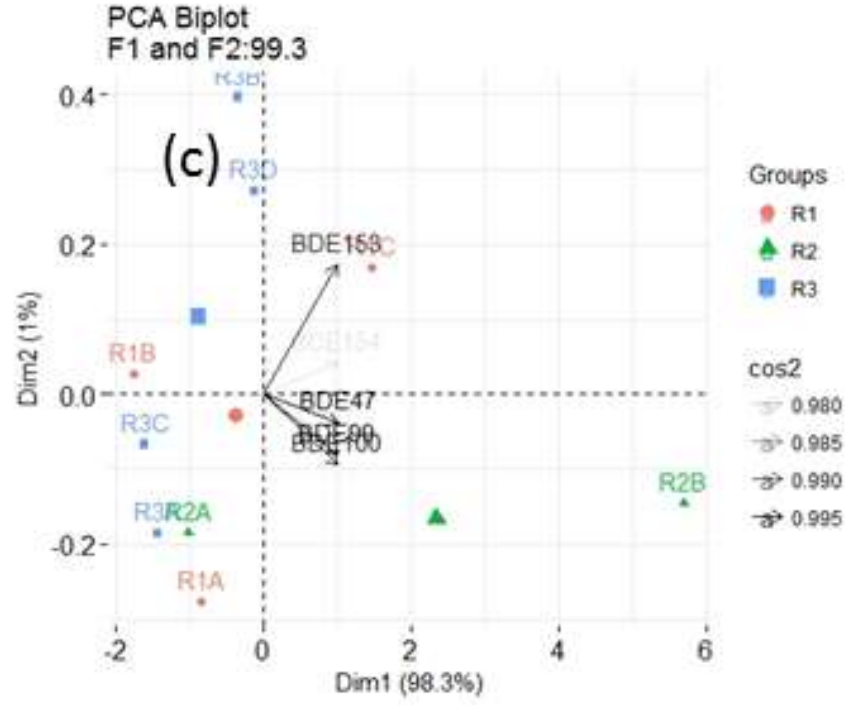

893

894

895

896

897

898

899 